\title{
Shifting landscapes of coastal flood risk: environmental (in)justice of urban change, sea level rise, and differential vulnerability in New York City
}

Pablo Herreros-Cantis ${ }^{1 *}$ (D), Veronica Olivotto ${ }^{1,2}$, Zbigniew J. Grabowski ${ }^{1,3}$ and Timon McPhearson ${ }^{1,3,4}$

* Correspondence: herrerop@ newschool.edu

${ }^{1}$ Urban Systems Lab, The New School, New York, NY, USA

Full list of author information is available at the end of the article

\begin{abstract}
Climate-driven changes in coastal flood risk have enormous consequences for coastal cities. These risks intersect with unequal patterns of environmental hazards exacerbating differential vulnerability of climate related flooding. Here we analyze differential vulnerability of coastal flooding in New York City, USA, as an environmental justice issue caused by shifts in flood risk due to increasing floodplain extents. These extents are represented by updates to the 100-year floodplain by the Federal Emergency Management Agency, and urban changes in land use, land value, and socio-economic characteristics of flood exposed populations. We focus on six local community districts containing disproportionately vulnerable communities. Across our study areas, we observed increases in the floodplain's extent by $45.7 \%$, total exposed population by $10.5 \%$, and population living in vulnerable communities by $7.5 \%$. Overall flood risk increases regardless of increases in the updated floodplain extent, as do floodplain property values. However, variability is high between community districts; in some cases, increases in exposure coincide with decreases in vulnerability due to shifts in racial demographics and increases in income (i.e. potential floodplain gentrification), while others experienced increases in exposure and vulnerability (i.e. double jeopardy). These findings highlight that the dominant drivers of coastal flood risk in NYC are ongoing real estate development and continued increases in sea level rise and storm severity, both of which have explicit implications for flood vulnerability. We describe the social processes governing development in the flood zone, namely zoning, resilience planning, and the determination of potential flooding severity and related insurance rates. We also discuss how these social drivers of risk intersect with social dimensions of vulnerability due to racist housing markets, and the distributions of public housing and toxic chemical hazards. We conclude with a framework for the analysis of contextual and outcome-based vulnerability to coastal flood hazards, and provide policy recommendations to reduce risks over the medium to long term.
\end{abstract}

Keywords: Coastal flooding, Flood risk, Flood hazard, Floodplain, Sea level rise, Environmental justice, Exposure, Vulnerability, Spatial analysis 


\section{Science highlights}

- Despite policy efforts, coastal flood risks to humans and buildings are increasing in NYC

- Floodplain development and population growth increases flood risk regardless of floodplain expansion

- Floodplain updates significantly increase exposure of people and buildings to flooding

- Populations added to the updated floodplain appear less vulnerable, except in areas with new development.

- Minor changes in floodplain boundaries have large implications for exposure

\section{Policy and practice recommendations}

- Coastal flood resilience efforts must account for differential vulnerability of urban residents

- Risk reduction must target development and population change on flood zones

- Risk reduction requires considering projected increases in flood risk due to climate change

- Significant uncertainties in current and future flood extents justify precautionary approaches

\section{Introduction}

New York City (NYC) has experienced significant coastal flooding events during the past decade. During Superstorm Sandy in 2012, ten to eleven feet of floodwaters permeated coastal Manhattan, Brooklyn, and Staten Island, killing 44 people, costing US\$19 Billion in direct economic damages (City of new York 2013), and inundating more than 88,000 buildings (Garner et al. 2017). Critical infrastructure systems during this extreme event were seriously damaged and had extensive recovery periods to restore basic services (Comes and de Walle 2014), leaving many residents with lasting health impacts, especially among the displaced (Neria and Shultz 2012; Schwartz et al. 2015, 2016; Schwartz et al. 2017). Tides observed during Sandy were the highest since records began in the 1700s (Orton et al. 2016), and combined with observed sea level rise, spurred the city and federal governments to invest heavily in coastal flood resilience planning. At the same time, the Federal Emergency Management Agency (FEMA) proposed an updated flood risk map for the city with a 1 in 100-year Special Flood Hazard Area in 2013 (SFHA), which was subsequently appealed by city government. Here we examine the pre-and post-Sandy social and built environment distributions of flood exposure comparing the existing versus updated 1 in 100-year SFHA using an environmental justice (EJ) analytical framework that includes assessing unevenness of social vulnerability to flooding.

\section{Environmental justice of urban flooding and flood risk management}

Sandy's impacts in NYC were unevenly experienced along lines of race and class (Sellers n.d.; Rohde 2012; Faber 2015), highlighting (EJ) concerns around the flood exposure of impoverished and segregated communities (Colten 2007; Bullard and 
Wright 2009; Walker and Burningham 2011; Chakraborty et al. 2019). EJ scholarship in the USA has previously examined spatial and procedural dimensions of the uneven distribution of anthropogenic hazards such as toxic chemicals and waste management facilities (Chakraborty et al. 2011). This work demonstrates that race and class drive community exposure to toxic chemical pollution through air, soil, and water (Collins et al. 2016; Landrigan et al. 2018). However, attempts to examine flood risk through an EJ lens, defined as the consequences of potential floods of different return periods (e.g. 1 in 100 year, 1 in 500 year) delineated by floodplains, identify paradoxical patterns of flood exposure. While more vulnerable communities are often more exposed to floods (Chakraborty et al. 2014; Grineski et al. 2015), in other regions more affluent communities have higher flood exposure (Collins et al. 2018). According to Collins et al. (2018), these patterns are driven by the amenity value of certain coastal zones (e.g. beachfront property which attracts affluent communities), as well as the failure to internalize vulnerability within definitions of flood risk itself, instead treating it as a characteristic of the at-risk population, or what some call 'outcome based' vulnerability (O'Brien et al. 2007).

Besides the uneven distribution of flood risk itself, the delineation of risks and their management may have important EJ consequences. Risk management relies on knowledge systems that define methodologies, and thresholds that must be agreed upon. These systems perceive climate related risks at different social, spatial, and temporal scales, inducing a "scalar politics" whereby actors view for legitimacy in framing risks and appropriate responses (Rozance et al. 2019). In the USA, flood risk is most often represented by floodplain delineation of the SFHA performed by FEMA as described above. Within the SFHA, buildings within the floodplain that have a federally backed mortgage, or have received federal disaster assistance require flood insurance (NYC Planning 2016), offered through the National Flood Insurance Program (NFIP), with rates set by Flood Insurance Rate Maps (FIRM). These variable insurance rates rely on a detailed analysis of the biophysical patterns of flood severity and building level structural resilience to flooding. In the SFHA case, the production of the flood maps focuses on representing current flood risk based on an assessment of historical patterns of flood related information and current conditions of the coastline and built infrastructures through a largely technical knowledge system (FEMA 2007, FEMA 2013, Hobbins et al. in press). Once the preliminary flood map is produced by FEMA, the map is open for public consultation by citizens, civil society groups and government agencies, who can appeal and demand its revision (Pralle 2019). While some communities, such as NYC, appealed against the boundaries of the preliminary floodplain, many other municipalities, communities, and individual property owners might not have had the resources to file an appeal, raising nationwide questions of equity relating to who has the time, money and political clout to file such appeals (Pralle 2019). In this sense, flood risk mapping itself can exacerbate existing injustices and inequalities by misrepresenting certain communities through mapping biases (Maantay and Maroko 2009), driving gentrification (DuPuis and Greenberg 2019), introducing a new economic burden through the NFIP's enforced regulations (Elliott 2019; Paganini 2019), unevenly distributing financial aid and buyouts programs (Howell and Elliott 2018; Siders 2019), incentivizing floodplain development (Wriggins 2014) even when empirical evidence suggests that development in flood-prone areas is fiscally irresponsible (Freudenberg 
et al. 2016), and relocating communities to even more vulnerable areas (McGhee et al. 2019). Aside from appealing floodplain updates, individuals and agencies may request updates to the effective floodplain in response to a perceived or experienced need for a more accurate representation of flood probability and extent, including reductions in floodplains following improvements to flood defense infrastructure. This request is submitted as a Letter of Map Change (LOMC), by which the applicant provides the information needed to demonstrate that their property or an area does not flood as the effective floodplain claims (FEMA 2020).

\section{The re-delineation of flood risk in a post-Sandy New York City}

Many of the areas severely affected by Sandy were outside of the effective SFHA (Dixon et al. 2013; Xian et al. 2015), developed in 1983 and revised in September 2007 (FEMA 2007). The term "effective" is used by FEMA as its boundaries determine the application of regulations and sanctions of the National Flood Insurance Program (NFIP). The 2013 FEMA update of NYC's SFHA, is based on more precise topographic data, more recent climatological data, and updated hydrological models (FEMA 2013). Updates to FEMA's flood maps are labelled as "preliminary" during the period in which these can be reviewed and contested by affected communities. Preliminary updates are not official and have no impact on the enforcement of the NFIP program until they are final and become effective, replacing the previous effective map (FEMA 2019a, 2019b). NYC's preliminary update indicated a much larger SFHA than the effective version, increasing the population within the floodplain by more than 400,000, and doubling the number of flood exposed buildings according to calculations made by the city (Buckley 2013). More than one third of the preliminary SFHA's population have average incomes of less than $\$ 75,000$ per year (Dixon et al. 2013). Flood-prone New Yorkers are $55 \%$ white, $26 \%$ black, 10\% Asian and 10\% "other", and a greater proportion of people are 70 years old and over compared to the city average (11\% VS $8 \%)$. The City appealed the updated flood risk maps alleging explicit methodological inconsistencies between FEMA's 2013 and 2007 studies, emphasizing that the storms selected for the 2013 model overestimated risk (Zarrilli 2015). However, the city's appeal also declared the need to reconsider floodplain extents due to the economic burden facing residents within the SFHA imposed by flood insurance requirements, adding a political dimension to the process (Chen 2018). As a result of the appeal, FEMA and NYC have embarked on yet another redrawing of the SFHA, during which the 2007 maps will remain effective for the purposes of the NFIP, leaving many homeowners uncertain of their flood exposure (Chen 2018; Enman 2019).

\section{Research objectives}

While FEMA and NYC work on a new coastal study that satisfies both ends, climatedriven sea level rise (SLR) and the increasing severity and frequency of extreme weather events continue to exacerbate urban coastal flood risk globally, with significant regional variation (Brown et al. 2018). The north-eastern seaboard of the United States faces higher rates of SLR due to the combination of the land mass sinking due to long term glacial retreat, and interactions between changes in temperature, salinity, and oceanic currents (Sallenger et al. 2012). Impacts of SLR represent both an existential and 
economic challenge for NYC since urban flooding has the highest economic impact of any natural hazard (Depietri and McPhearson 2018). Planners and policy-makers need updated information regarding the evolution of flood risk in the city in order to understand its drivers of change and its distribution across differently vulnerable communities. In this study we asked: How is coastal flood risk changing in New York City, and what are its environmental justice implications?

Previous studies have looked at the possible effects of rising flood insurance premiums between different floodplains focusing on particular housing typologies (Dixon et al. 2013) as well as on the social reproduction of historically disenfranchised groups (Paganini 2019). Here we go further to systematically unpack the differences in hazard probability, exposure and vulnerability within some of the most vulnerable Community Districts across time, between varying SFHAs as well as outside floodplains. We examined flood risk changes for the period between 2007 and 2018, a time frame allowing for pre- and post- Sandy comparison. Disaster risk is generally defined as an aggregate of three context-specific attributes: hazard, exposure and vulnerability (see Table 1 for detailed definitions), forming the "risk triangle" (Crichton 1999; Kaźmierczak and Cavan 2011). Each attribute changes over space and time. While climate change directly affects the probability and intensity of natural events to occur (hazard), exposure and vulnerability may shift due to different drivers, such as land use and demographic changes. For example, human exposure to flooding may vary across areas with different population densities, and across time due to demographic changes or densification of the built environment. Built environment and socio-demographic changes that define exposure and vulnerability occur largely within defined, rather stable spatial units (e.g. defined tax lots, census blocks) and can be readily traced through time. In contrast, redrawing the SFHA is inherently a spatial change, and it can incorporate or subtract areas and the buildings and populations within them. This means that changes in exposure and vulnerability through time and space must be carefully disentangled. Consequently, we break down our research into four subquestions that isolate changes in exposure and vulnerability linked to urban change over time from those related to the redrawing of the SFHA: RQ1) How did flood risk change across time within the effective SFHA?, RQ2) How do the representations of flood hazard by the preliminary and the effective floodplains differ?, RQ3) How does exposure and vulnerability of populations and buildings change within the preliminary floodplain compared against the effective floodplain?, RQ4) Are there significant

Table 1 Definitions of risk, hazard, exposure and vulnerability according to the IPCC (2012, p.32)

\begin{tabular}{ll}
\hline Risk & "the likelihood over a specified time period of severe alterations in the normal functioning of a \\
& community or a society due to hazardous physical events interacting with vulnerable social \\
& conditions, leading to widespread adverse human, material, economic, or environmental effects \\
& that require immediate emergency response to satisfy critical human needs and that may require \\
& external support for recovery" \\
& "The potential occurrence of a natural or human-induced physical event that may cause loss of \\
Hazard & life, injury, or other health impacts, as well as damage and loss to property, infrastructure, liveli \\
& hoods, service provision, and environmental resources". \\
& "The presence (location) of people, livelihoods, environmental services and resources, \\
& infrastructure, or economic, social, or cultural assets in places that could be adversely affected by \\
& physical events and which, thereby, are subject to potential future harm, loss, or damage". \\
Vulnerability & "The characteristics of a person or group and their situation that influences their capacity to \\
& anticipate, cope with, resist, and recover from the adverse effects of physical events".
\end{tabular}


differences in vulnerability between the exposed and the non-exposed populations to the SFHA according to its preliminary update?

RQ1 considers shifts in risk due to exposure and vulnerability changes within the currently effective floodplain. RQ2 examines the changes in hazard probability by comparing extents of the effective floodplain and its preliminary update. RQ3 focuses on the consequences of adding/removing new areas and populations to the floodplain due to the re-drawing. Finally, RQ4 refers to the distributional justice of flood risk within each Community District (CD), by comparing the vulnerability of those exposed and non-exposed communities.

\section{Methods}

Because we expect changes in risk to be spatially explicit and subject to local contexts changing within the city, our study focused on tracking changes in risk across a selection of CDs within NYC. By examining intra-city change we were able to reflect on the spatial idiosyncrasy and/or generalizability of our results. CDs selection for this study was driven by multiple criteria. First, we included at least one CD per borough, in order to incorporate areas with different geographies, legacies, and characteristics. Second, CDs that were highly impacted by Superstorm Sandy were prioritized in order to keep a focus on areas that have been impacted by previous flood events. Impact was considered in terms of a) percentage of the total population affected and b) percentage of the District's area flooded. The population affected by Superstorm Sandy was estimated as the sum of the total population of the 2010 census blocks that intersected with the Superstorm's flooded area (SBS 2015). Third, we prioritized CDs with a high proportion (at least more than 50\%) of their population living in New York State Potential Environmental Justice Areas (PEJAs). A PEJA is defined as "a minority or low-income community that may bear a disproportionate share of the negative environmental consequences resulting from industrial, municipal, and commercial operations or the execution of federal, state, local, and tribal programs and policies" (NYS Department of Environmental Conservation 2003). The NYS Department of Environmental Conservation defines PEJAs as census block groups that meet or exceed at least one of the two thresholds in urban areas: At least $51.1 \%$ of the population self-reported to be members of minority groups (identified or recognized by the U.S. Census Bureau as Hispanic, African-American or Black, Asian and Pacific Islander or American Indian), and at least 23.59\% of the population had household incomes below the federal poverty level. 2010 census data was used for mapping different racial and ethnic groups, while the ACS estimates 2009-2013 were used to quantify the percentage of low-income households at the time of Superstorm Sandy.

Six CDs were then selected from the above criteria: Lower East Side (103) and East Harlem (111) in Manhattan, the area comprised by City Island/Co-op City and others (210) in the Bronx, Coney Island (313) in Brooklyn, the Rockaways (414) in Queens and Stapleton (501) in Staten Island. Table 2 summarizes the criteria used to select these CDs, while Fig. 1 provides a map of the CDs and their PEJAs. CDs have different characteristics that influence their urban form and might affect the results obtained during the analysis. For example, CDs differ in their predominant residential land use type (NYC Planning n.d.-a, n.d.-b). In City Island/Co-op City (210) and the Rockaways (414), single family buildings are predominant in areas near the coast. These are areas 
Table 2 Indicators used to select the studied CDs. In the titles row, brackets mean average values for all the CDs that flooded during Superstorm Sandy

\begin{tabular}{|c|c|c|c|c|c|}
\hline $\begin{array}{l}\text { CD name in } \\
\text { this study }\end{array}$ & $\begin{array}{l}C D \\
\text { code }\end{array}$ & $\begin{array}{l}\text { Total population - } 2010 \\
\text { census }(145,301)\end{array}$ & $\begin{array}{l}\text { Population affected } \\
\text { by Sandy }(12.5 \%)\end{array}$ & $\begin{array}{l}\text { Area flooded by } \\
\text { Sandy }(12.2 \%)\end{array}$ & $\begin{array}{l}\text { Population living } \\
\text { in PEJAs (68\%) }\end{array}$ \\
\hline $\begin{array}{l}\text { Lower East } \\
\text { Side }\end{array}$ & 103 & 163,277 & $31.1 \%$ & $25.0 \%$ & $68.3 \%$ \\
\hline East Harlem & 111 & 120,511 & $40.0 \%$ & $19.7 \%$ & $94.6 \%$ \\
\hline $\begin{array}{l}\text { City Island/ } \\
\text { Co-op City }\end{array}$ & 210 & 120,800 & $12.8 \%$ & $10.3 \%$ & $67.5 \%$ \\
\hline Coney Island & 313 & 104,400 & $99.67 \%$ & $84.4 \%$ & $57.1 \%$ \\
\hline $\begin{array}{l}\text { The } \\
\text { Rockaways }\end{array}$ & 414 & 114,978 & $85.8 \%$ & $72.4 \%$ & $69.5 \%$ \\
\hline Stapleton & 501 & 175,756 & $8.7 \%$ & $12.1 \%$ & $67.8 \%$ \\
\hline
\end{tabular}

with low population and built densities and with significant access to water-related amenities. In the Rockaways, the West end of the peninsula, where these low density communities are located, the population has a much higher proportion of owned housing units and white residents than the East end, where PEJAs were identified (Graham et al. 2016). Other CDs, such as East Harlem (111) and Lower East Side (103) have a much higher population density, and multi-family buildings prevail. To provide context on the differences between CDs, Table 3 shows the distribution of land use categories and race.

We carried out comparisons between two different moments in time and two different geographies for each research question. The datasets used were MapPLUTO's dataset for 2007 (version 07c), year in which the effective floodplain was last updated, and 2018 (version 18v1), the most updated dataset at the time of this analysis. MapPLUTO is the georeferenced version of the Primary Land Use Tax Lot Output

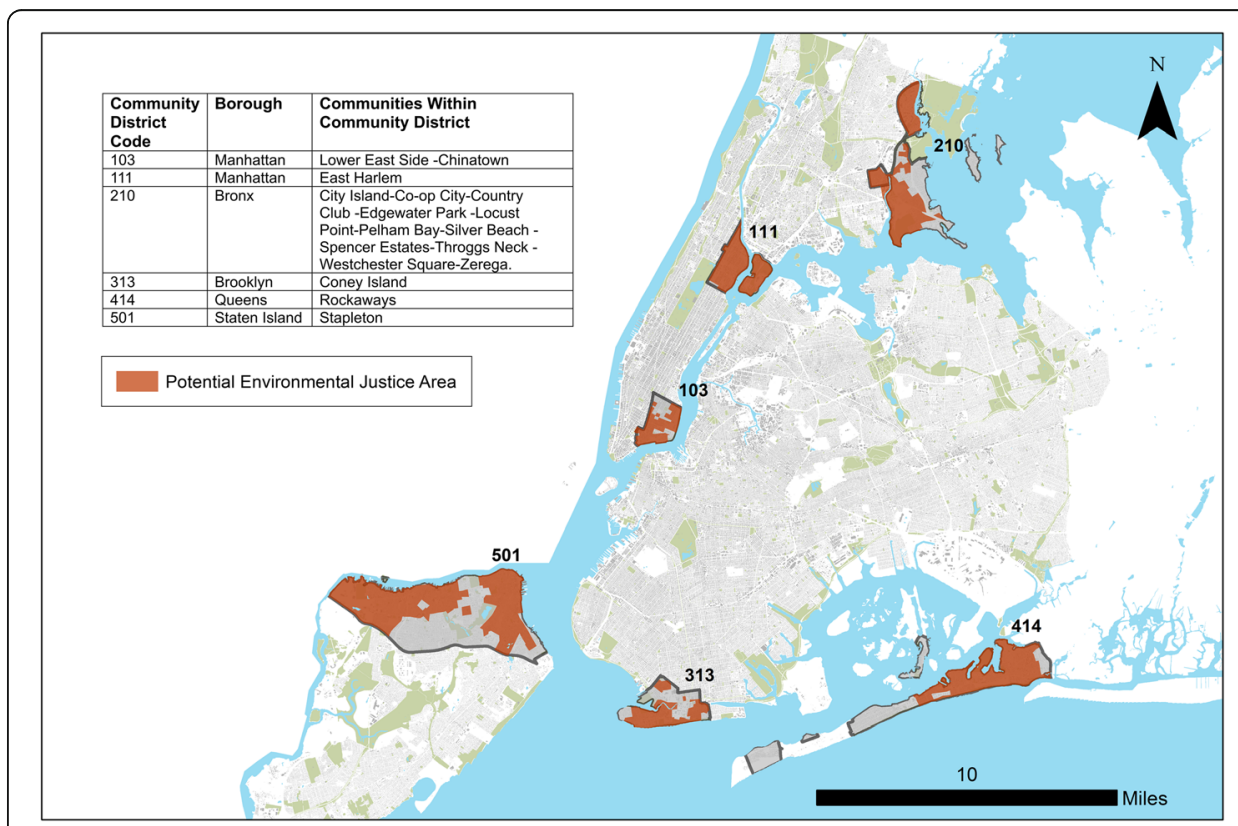

Fig. 1 Location of the NYC CDs selected for this study, their corresponding codes, boroughs, communities contained within them and the portion that is considered a Potential Environmental Justice Area 
Table 3 Land use and race distributions in percentage across the selected CDs, according to MapPLUTO (2018) and ACS (2013-2017)

\begin{tabular}{lllllll}
\hline LANDUSE & 103 & 111 & 210 & 313 & 414 & 501 \\
\hline Unknown & $0.2 \%$ & $0.1 \%$ & $0.9 \%$ & $0.8 \%$ & $0.6 \%$ & $0.8 \%$ \\
One- \& Two-Family Buildings & $0.3 \%$ & $0.4 \%$ & $32.9 \%$ & $13.6 \%$ & $41.2 \%$ & $43.9 \%$ \\
Multi - Family Walk- Up Buildings & $19.3 \%$ & $7.3 \%$ & $6.9 \%$ & $7.6 \%$ & $4.2 \%$ & $4.6 \%$ \\
Multi - Family Elevator Buildings & $25.5 \%$ & $19.5 \%$ & $8.0 \%$ & $18.0 \%$ & $7.9 \%$ & $2.1 \%$ \\
Mixed Residential \& Commercial Buildings & $17.1 \%$ & $5.9 \%$ & $1.4 \%$ & $4.7 \%$ & $0.9 \%$ & $1.6 \%$ \\
Commercial and Office Buildings & $3.8 \%$ & $2.3 \%$ & $8.1 \%$ & $3.8 \%$ & $2.1 \%$ & $5.0 \%$ \\
Industrial and Manufacturing & $1.1 \%$ & $0.6 \%$ & $1.8 \%$ & $1.0 \%$ & $0.8 \%$ & $3.1 \%$ \\
Transportation and Utility & $3.8 \%$ & $9.4 \%$ & $0.9 \%$ & $7.9 \%$ & $4.1 \%$ & $8.6 \%$ \\
Public Facilities and Institutions & $11.2 \%$ & $10.6 \%$ & $11.0 \%$ & $7.7 \%$ & $5.5 \%$ & $6.5 \%$ \\
Open Space and Outdoor Recreation & $14.2 \%$ & $40.0 \%$ & $21.3 \%$ & $24.9 \%$ & $19.9 \%$ & $13.9 \%$ \\
Parking Facilities & $1.3 \%$ & $1.9 \%$ & $2.3 \%$ & $3.0 \%$ & $1.1 \%$ & $1.5 \%$ \\
Vacant Land & $2.0 \%$ & $2.0 \%$ & $4.4 \%$ & $7.2 \%$ & $11.8 \%$ & $8.5 \%$ \\
RACE \& ETHNICITY & $\mathbf{1 0 3}$ & $\mathbf{1 1 1}$ & $\mathbf{2 1 0}$ & $\mathbf{3 1 3}$ & $\mathbf{4 1 4}$ & $\mathbf{5 0 1}$ \\
White & $32.8 \%$ & $13.8 \%$ & $27.2 \%$ & $56.6 \%$ & $34.7 \%$ & $38.2 \%$ \\
Black/African American & $7.3 \%$ & $30.7 \%$ & $23.3 \%$ & $12.7 \%$ & $35.4 \%$ & $21.5 \%$ \\
Hispanic/Latino & $25.1 \%$ & $45.7 \%$ & $41.8 \%$ & $16.0 \%$ & $24.6 \%$ & $29.6 \%$ \\
Asian & $32.0 \%$ & $7.7 \%$ & $5.6 \%$ & $12.6 \%$ & $3.5 \%$ & $7.6 \%$ \\
American Indian / Alaska Native & $0.3 \%$ & $0.0 \%$ & $0.1 \%$ & $0.3 \%$ & $0.1 \%$ & $0.2 \%$ \\
Native Hawaiian / Other Pacific Islander & $0.0 \%$ & $0.1 \%$ & $0.0 \%$ & $0.0 \%$ & $0.1 \%$ & $0.0 \%$ \\
Some other race & $0.4 \%$ & $0.6 \%$ & $0.9 \%$ & $0.3 \%$ & $0.8 \%$ & $0.4 \%$ \\
Two or more races & $2.0 \%$ & $1.4 \%$ & $1.1 \%$ & $1.6 \%$ & $1.0 \%$ & $2.6 \%$ \\
\hline
\end{tabular}

(PLUTO) for NYC, and can be extracted from the Bytes of the Big Apple platform (NYC Planning n.d.-a, n.d.-b). This dataset contains extensive information on land use area and assessed total land value at the tax lot level. Social vulnerability indicators were obtained from the American Community Survey (ACS) at the census block group level. In order to reduce uncertainty in ACS estimates and increase spatial resolution to the block group level, we use ACS 5-year data (US Census Bureau n.d.-a, n.d.-b). The 5-year estimates for 2006-2010 and 2013-2017 were used. For clarity, we label our compared time periods as 2007 and 2018 in the plotted results produced. Floodplain maps indicating the location of the effective (FEMA 2007) and preliminary (FEMA 2013). SFHAs were retrieved from FEMA's Mapping Service Center (FEMA n.d.). The SFHAs were used to classify the areas in each CD that intersected with a floodplain as exposed to flooding. Socio-economic data was then aggregated within exposed and non-exposed areas to compare how exposure and vulnerability indicators reflected different risk levels. While we are aware of the discrepancies and ongoing analysis around the updated SFHA, which is subject to change, it is important to examine potential impacts of this potential change in the designated floodplain and how it may impact the distribution of coastal flood risk. Furthermore, the coastal re-study currently being developed by FEMA due to NYC's appeal is not expected to be released until 2024 (Enman 2019), making the 2013 preliminary map the most updated official flood risk map available for comparison against the effective one. 
Table 4 summarizes the focus of each research question and the data used. Figure 2 provides a graphic description of how the different samples were generated combining exposure and vulnerability indicators with the different floodplains.

Table 5 shows the indicators that were used to track changes in both exposure and vulnerability. The selection of these indicators was based on other similar studies (Burby 2001; Walker and Burningham 2011; de Moel and Aerts 2011; Camarasa-Belmonte and Soriano-García 2012; Koks et al. 2015) and the availability of data comparable across time.

Raw data retrieved from the ACS required aggregation and processing in order to represent the desired information. For example, the amount of people that spoke little or no English was disaggregated by age and gender, whereas we show a total value. Because the ACS is composed of estimates, there are margins of error associated with each measurement that have implications for data processing and analysis. Error propagation was managed using the formulas indicated by the US Census Bureau (US Census Bureau n.d.-a, n.d.-b). Margins of error were used to check statistical significance in the difference between compared geographies by calculating their z-scores:

$$
z-\operatorname{score}_{A, B}=\frac{A-B}{\sqrt{[S E(\mathrm{~A})]^{2}+[S E(\mathrm{~B})]^{2}}}
$$

Table 4 Summary of the data compared per research question. The samples compared differed in the geography used to aggregate data or the year in which the data was collected

\begin{tabular}{|c|c|c|c|c|c|c|c|}
\hline \multirow[t]{2}{*}{$\mathrm{RQ}$} & \multirow[t]{2}{*}{ Focus } & \multirow{2}{*}{$\begin{array}{l}\text { Data to } \\
\text { compare }\end{array}$} & \multirow{2}{*}{$\begin{array}{l}\text { Comparison } \\
\text { across }\end{array}$} & \multicolumn{2}{|l|}{ Sample 1} & \multicolumn{2}{|l|}{ Sample 2} \\
\hline & & & & Geography & $\begin{array}{l}\text { Data } \\
\text { source / } \\
\text { year }\end{array}$ & Geography & $\begin{array}{l}\text { Data } \\
\text { source / } \\
\text { year }\end{array}$ \\
\hline 1 & $\begin{array}{l}\text { Flood risk changes } \\
\text { across time within } \\
\text { the effective SFHA. }\end{array}$ & $\begin{array}{l}\text { Exposure and } \\
\text { vulnerability } \\
\text { indicators. }\end{array}$ & Time & $\begin{array}{l}\text { Effective } \\
\text { floodplain. }\end{array}$ & $\begin{array}{l}\text { MapPLUTO } \\
\text { 2007; ACS } \\
2006-2010 .\end{array}$ & $\begin{array}{l}\text { Effective } \\
\text { floodplain. }\end{array}$ & $\begin{array}{l}\text { MapPLUTO } \\
\text { 2018; ACS } \\
\text { 2013-2017. }\end{array}$ \\
\hline 2 & $\begin{array}{l}\text { Flood hazard } \\
\text { changes due to the } \\
\text { shift from effective } \\
\text { to preliminary } \\
\text { SFHA. }\end{array}$ & $\begin{array}{l}\text { Total and \% } \\
\text { area flooded, } \\
\text { according to } \\
\text { the effective } \\
\text { and the } \\
\text { preliminary } \\
\text { floodplains. }\end{array}$ & Space & $\begin{array}{l}\text { Effective } \\
\text { floodplain. }\end{array}$ & $\begin{array}{l}\text { FEMA } \\
\text { Mapping } \\
\text { Service } \\
\text { center } \\
\text { (n.d.); FEMA } \\
2007 \text {. }\end{array}$ & $\begin{array}{l}\text { Preliminary } \\
\text { floodplain. }\end{array}$ & $\begin{array}{l}\text { FEMA } \\
\text { Mapping } \\
\text { Service } \\
\text { center } \\
\text { (n.d.); FEMA } \\
\text { 2013. }\end{array}$ \\
\hline 3 & $\begin{array}{l}\text { Flood risk changes } \\
\text { due to adoption of } \\
\text { the preliminary } \\
\text { SFHA by adding } \\
\text { and/or removing } \\
\text { exposed areas and } \\
\text { communities. }\end{array}$ & $\begin{array}{l}\text { Exposure and } \\
\text { vulnerability } \\
\text { indicators. }\end{array}$ & Space & $\begin{array}{l}\text { Effective } \\
\text { floodplain. }\end{array}$ & $\begin{array}{l}\text { MapPLUTO } \\
\text { 2018; ACS } \\
2013-2017 .\end{array}$ & $\begin{array}{l}\text { Area added } \\
\text { to } \\
\text { floodplain } \\
\text { due to } \\
\text { expansion } \\
\text { in } \\
\text { preliminary } \\
\text { update. }\end{array}$ & $\begin{array}{l}\text { MapPLUTO } \\
\text { 2018; ACS } \\
\text { 2013-2017. }\end{array}$ \\
\hline 4 & $\begin{array}{l}\text { Differences in social } \\
\text { vulnerability } \\
\text { between exposed } \\
\text { and non-exposed } \\
\text { populations. }\end{array}$ & $\begin{array}{l}\text { Vulnerability } \\
\text { indicators. }\end{array}$ & Space & $\begin{array}{l}\text { Preliminary } \\
\text { floodplain }\end{array}$ & $\begin{array}{l}\text { ACS 2013- } \\
2017 .\end{array}$ & $\begin{array}{l}\text { Area } \\
\text { outside of } \\
\text { the } \\
\text { preliminary } \\
\text { floodplain }\end{array}$ & $\begin{array}{l}\text { ACS 2013- } \\
2017 .\end{array}$ \\
\hline
\end{tabular}




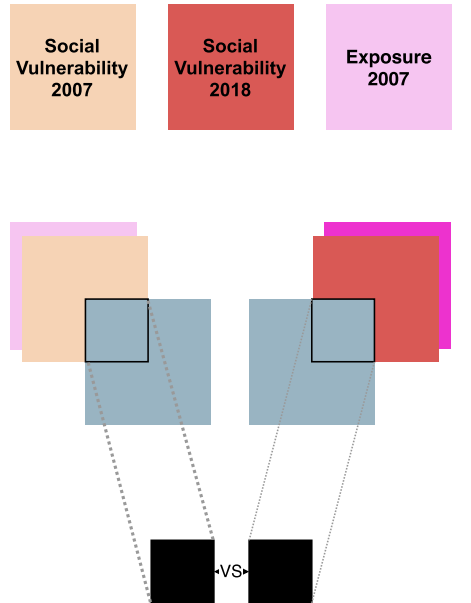

RQ1: Differences in exposure and vulnerability within the effective floodplain across time. Tax lots and census block groups intersecting with the effective floodplain were selected to then compare the indicators for 2007 and 2018 within a constant geography.

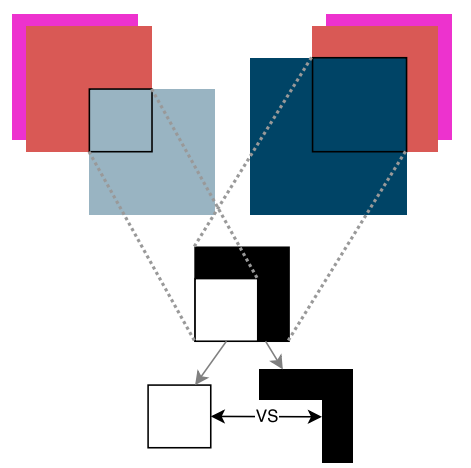

RQ3: Consequences of adding a new population to the floodplain. The increase in exposure was assessed by comparing the indicators between the totality of both

floodplains. Differences in vulnerability were assessed by comparing the population within the effective floodplain an the population within the newly added areas.
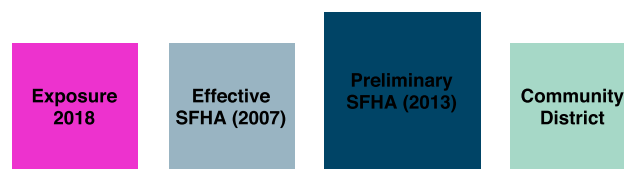

District
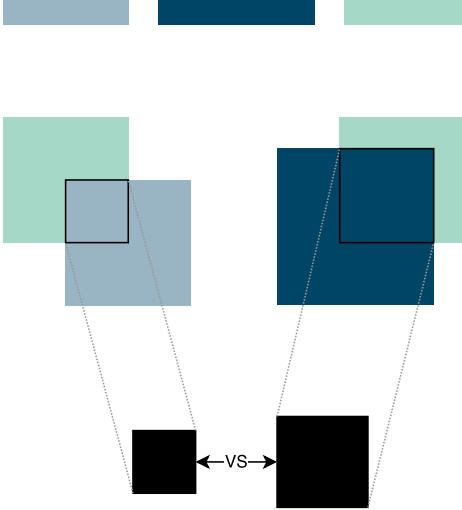

RQ2: Differences in flood hazard between the effective and preliminary floodplain. The parts of each floodplain intersecting with each $\mathrm{CD}$ were delineated to then compare their extent and the overall percentage of the CD flooded.

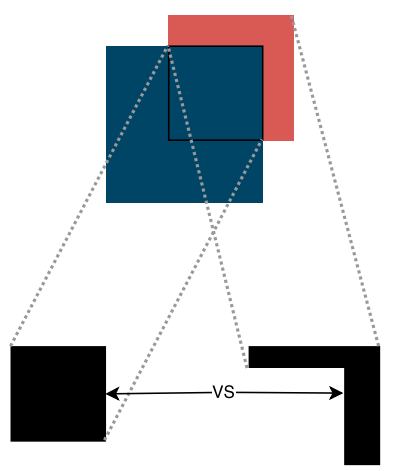

RQ4: Differences in vulnerability within the effective floodplain across time. Vulnerability indicators were compared between census block groups intersecting with
the preliminary floodplain and those that did not intersect.

Fig. 2 Graphic summary of the process by which, for each research question, different sub-areas were identified to then compare their exposure, vulnerability and hazard indicators across time or space

\section{Results}

We find that flood risk in the effective floodplain has increased or remained constant during the study period studied due primarily to shifts in exposure and vulnerability from land use, demographic and socio-economic changes. The preliminary floodplain implies an increase in the total extent of the floodplain (45.7\%), exposed population (10.5\%) and residents in PEJAs (7.6\%). The changes in floodplain extent vary across CDs. In some cases, the preliminary floodplain has an extent smaller than the effective floodplain, highlighting that the alterations of the SFHA based on the new coastal study carried out by FEMA are not homogeneous across space. In every CD, however, the population added to the preliminary floodplain is less vulnerable than the effective floodplain, with only East Harlem showing the opposite result. Finally, our comparison between the exposed and non-exposed populations within each CD show mixed results 
Table $\mathbf{5}$ Indicators used in the analysis of exposure and vulnerability changes across time and

\begin{tabular}{|c|c|c|}
\hline $\begin{array}{l}\text { Risk } \\
\text { component }\end{array}$ & Indicator name & Source dataset - field \\
\hline \multirow[t]{9}{*}{ Exposure } & Number of Buildings & $\begin{array}{l}\text { MapPluto - } \\
\text { NumBldgs }\end{array}$ \\
\hline & Number of Residential Units & MapPluto - UnitsRes \\
\hline & Residential area & MapPluto - ResArea \\
\hline & Industrial area & $\begin{array}{l}\text { MapPluto - } \\
\text { FactryArea }\end{array}$ \\
\hline & Commercial area & MapPluto - ComArea \\
\hline & Office area & $\begin{array}{l}\text { MapPluto - } \\
\text { OfficeArea }\end{array}$ \\
\hline & Total Land Value & $\begin{array}{l}\text { MapPLUTO - } \\
\text { AssessTot }\end{array}$ \\
\hline & Total Population & ACS - B01001 \\
\hline & Proportion of the population being people of color & ACS - B03002 \\
\hline \multirow[t]{9}{*}{ Vulnerability } & Population above 25 years old who didn't attend school & ACS - B15003 \\
\hline & Language isolated adults (speaks English "not well" and "not at all") & ACS $-16,004$ \\
\hline & Elderly population ( +65 years old) living alone & ACS - B09021 \\
\hline & Households living below the poverty level & ACS - B17017 \\
\hline & Households without a car & ACS - 25,044 \\
\hline & Rental households & ACS - B25003 \\
\hline & Single parents & ACS - B09002 \\
\hline & $\begin{array}{l}\text { Population within vulnerable ages (below } 15 \text { years old, above } 65 \text { years } \\
\text { old) }\end{array}$ & ACS - B01001 \\
\hline & Median income & ACS - B19013 \\
\hline
\end{tabular}

that are linked to the location of the PEJAs within each CD, as well as with the distribution of areas with higher amenity values. Below, we provide quantitative details about the results obtained for each research question.

How did flood risk change across time within the effective SFHA?

Overall, we observe a general increase in exposure over time in all CD's effective floodplains (SFHAs), although individual indicators vary between CDs (Fig. 3). The number of buildings has generally increased in the effective floodplain, coinciding with a growth in residential area and the number of residential units, with the exception of the Rockaways (414), which has a high proportion of low-density housing. Statistically significant population growth occurred in Coney Island (313, 6.5\%) and the Rockaways (414, 11.7\%). The proportion of people of color has also increased in some CDs, with a maximum increase in Stapleton (501, 5.0\%). This increase in exposure of people, buildings and homes implies a higher risk in the effective floodplain of CDs that were severely impacted by Sandy. Changes in land use within the floodplain vary significantly. In largely industrialized CDs such as Stapleton (501) and East Harlem (111), industrial land use has sharply declined ( $-47.5 \%$ and $-80.1 \%$ respectively), while City Island/Coop City (210), Coney Island (313), and the Rockaways (414) show small increases. 


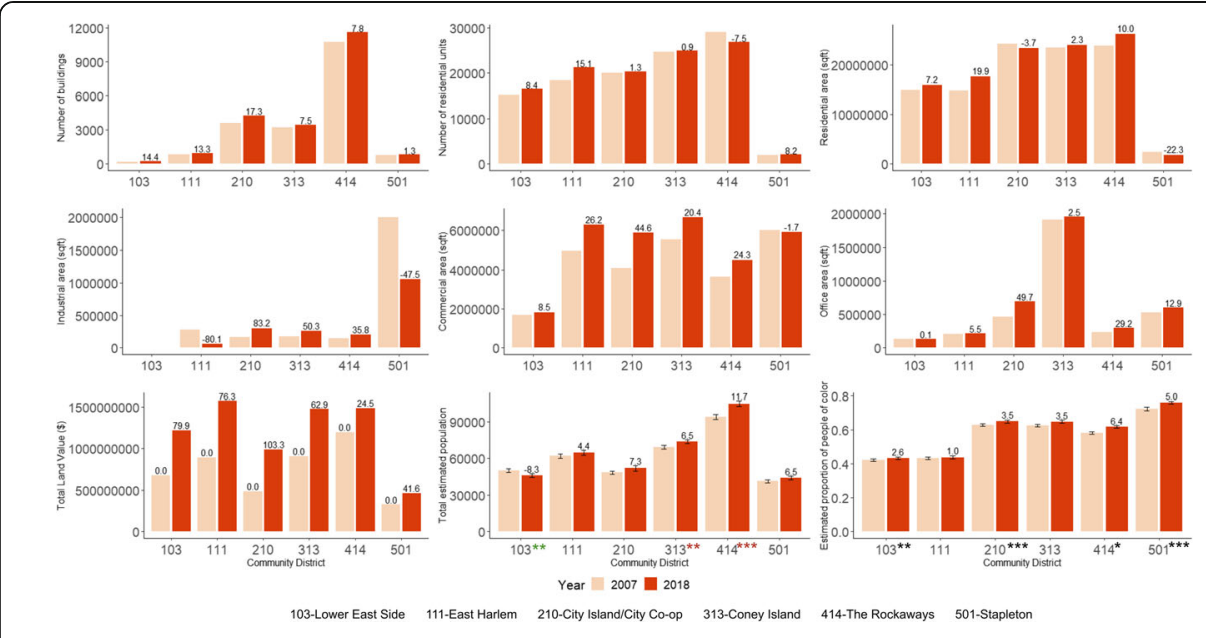

Fig. 3 Changes in exposure over time in FEMA's effective SFHA. Error bars represent the Standard Error of ACS estimates, and asterisks indicate $p$-values below $0.01\left(^{* * *}\right), 0.05\left(^{* *}\right)$ and $0.1\left(^{*}\right)$. No asterisk means that there is no statistically significant difference. Red asterisks indicate that exposure increases, while green asterisks indicate a decrease in exposure. Labels on top of each second bar indicate the \% increase

Commercial and office areas show a general increase, with the largest increases observed in City Island/Co-op City (210), as well as more exposed CDs such as Coney Island (313) and Rockaways (414). Land value has increased across every CD, ranging from $24.5 \%$ in Rockaways (414) and 103\% in City Island/Co-op City (210).

In contrast, vulnerability shows more nuanced patterns at the CD scale (Fig. 4), and our analysis exposes the multi-faceted nature of vulnerability driven by socio-economic changes. The most significant increases in vulnerability are related to a higher proportion of households living below the poverty level in East Harlem (111), Coney Island (313) and Stapleton (501) by $12.5,15.7$ and $33.5 \%$ respectively. Additionally, the proportion of elderly people living alone over the total population has increased in Lower East Side (103, 37.4\% increase) and East Harlem (111, 29.5\%), and the number of unschooled adults has significantly increased in Coney Island (313). There is no clear pattern regarding the ratio of rental households, where City Island/Co-op City (210) shows an increase in households and Coney Island (313) shows a decrease. Households with no car have decreased in Coney Island $(313,-8.7 \%)$ and the Rockaways $(414$, 14.7). Overall, these results are important as they indicate that changes in floodplain extent may mask changes of vulnerability due to urban land use and demographic change in certain neighborhoods.

\section{How do the representations of flood hazard by the preliminary and the effective floodplains differ?}

The extent of the preliminary and effective floodplains is significantly different. Across the six CDs studied, the total area of the preliminary floodplain (SFHA) is $3141.3 \mathrm{ha}$, meaning a $45.7 \%$ increase compared to the effective floodplain. However, the changes in the extent of the floodplain vary per CD (Fig. 5). For Coney Island (313), the preliminary SFHA places more than $80 \%$ of the CD under the 100 -year floodplain, or a $66.8 \%$ 


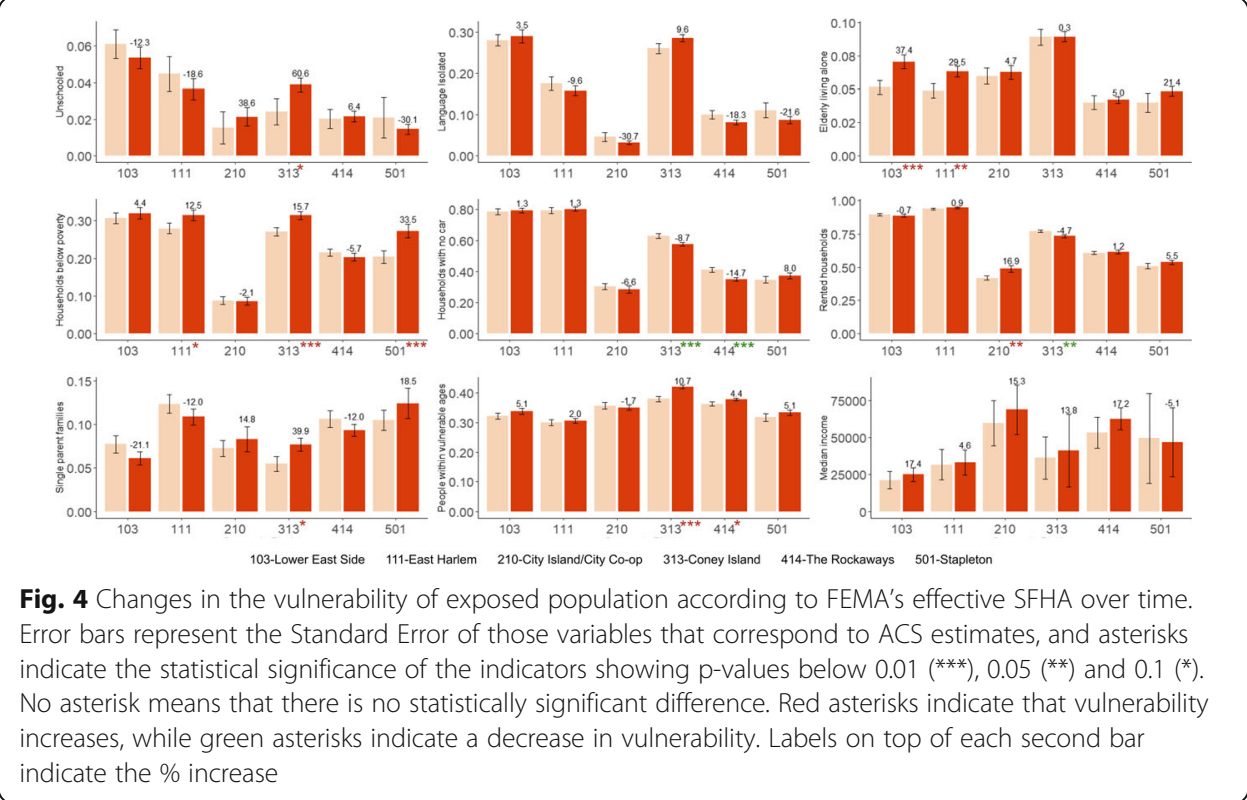

increment. In the Rockaways (414), more than $60 \%$ of the CD overlaps with the SFHA, or an increment of 50.9\%. Although in Lower East Side (103) and Stapleton (501) flood plain increases cover a small portion of the overall $C D$ area, change relative to the existing floodplain is high, increasing $113.2 \%$ in Stapleton and 55.1\% in the Lower East Side. In contrast, East Harlem (111) and City Island/Co-op City (210) had slight decreases in their updated floodplain areas $(-2.2 \%$ and $-4.3 \%$ respectively). The observed decrease in the extent of the floodplain in City Island / Co-op City (210) is explained by removal of the Co-op City development, a 600 acres middle income cooperative apartment complex where approx. 45,000 people live, from the preliminary floodplain. According to FEMA's Mapping Service Center (FEMA n.d.), no official revisions nor amendments were adopted in the area via an LOMC. Hence, the change in the floodplain's boundaries excluding the Co-op City development is most likely the result of the differences in the modelling approach taken (different methods and different data inputs). While these two CDs show a decrease in total area flooded, each CD counts with newly added to the floodplain, meaning that the floodplain has not shrank uniformly as a result of the coastal study, but was also transformed. Overall, these changes indicate that while large increases in flood likelihood are occurring within NYC, these changes can be highly localized and influenced by the ongoing process of delineating FEMA's floodplains.

How does exposure and vulnerability of populations and buildings change within the preliminary floodplain compared against the effective floodplain?

Exposure in NYC's CDs generally increases with the floodplain's redrawing (Fig. 6). Districts showing the largest growth in their floodplains such as Coney Island (313) and the Rockaways (414) also show large increases in exposure in terms of number of buildings, residential units, residential area, commercial area and their total estimated 


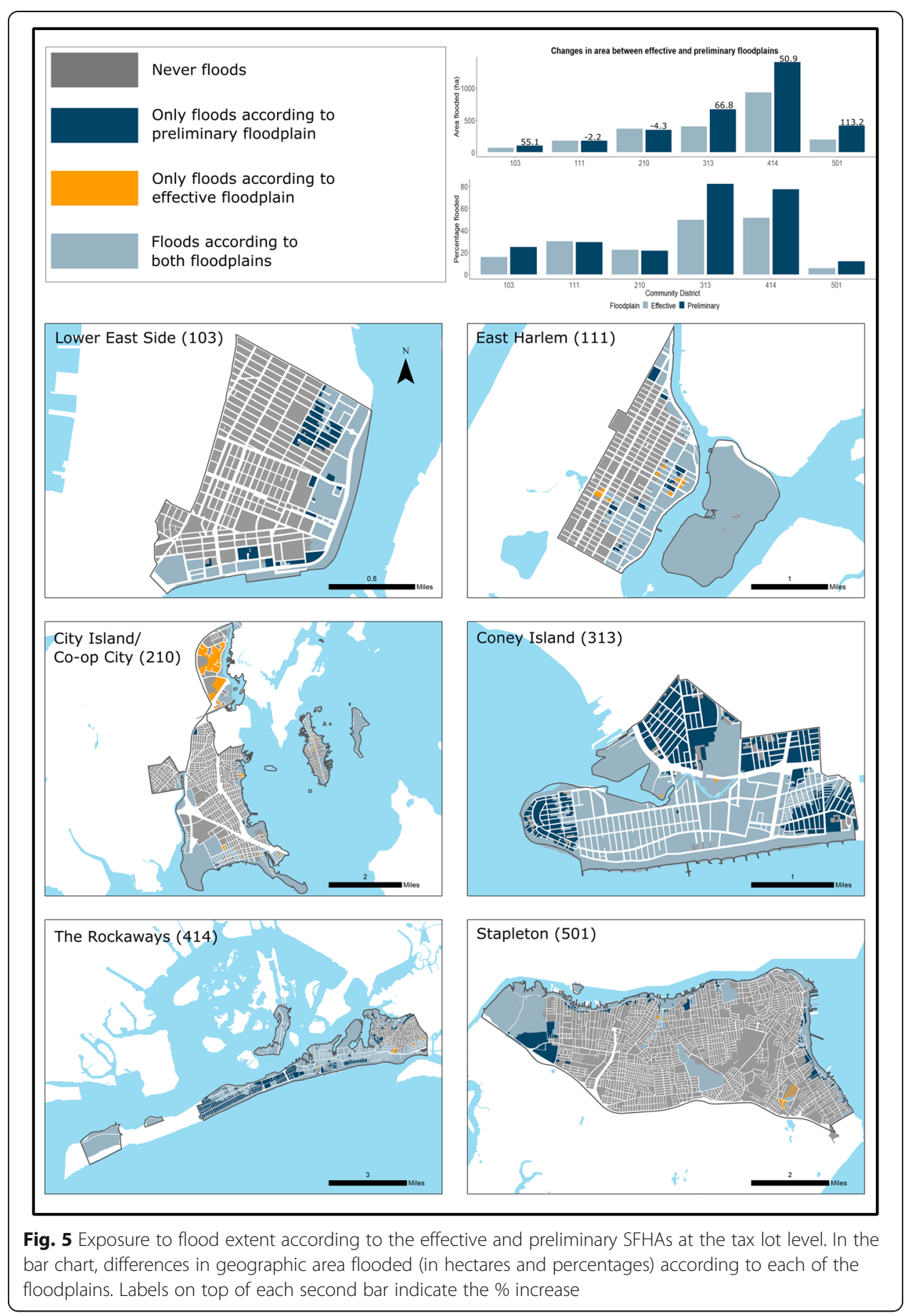

populations. In contrast, City Island/Co-op City (210), whose floodplain shows a slight decrease, experiences a large decrease in exposed residential units and commercial areas. This may be again explained by the Bronx's Co-op City development being excluded from the preliminary floodplain.

Shifts in industrial land use exposed due to the redrawing of the floodplain vary, but do not necessarily match with the changes within the effective floodplain. For example, while industrial land uses within the effective SFHA have decreased in East Harlem 


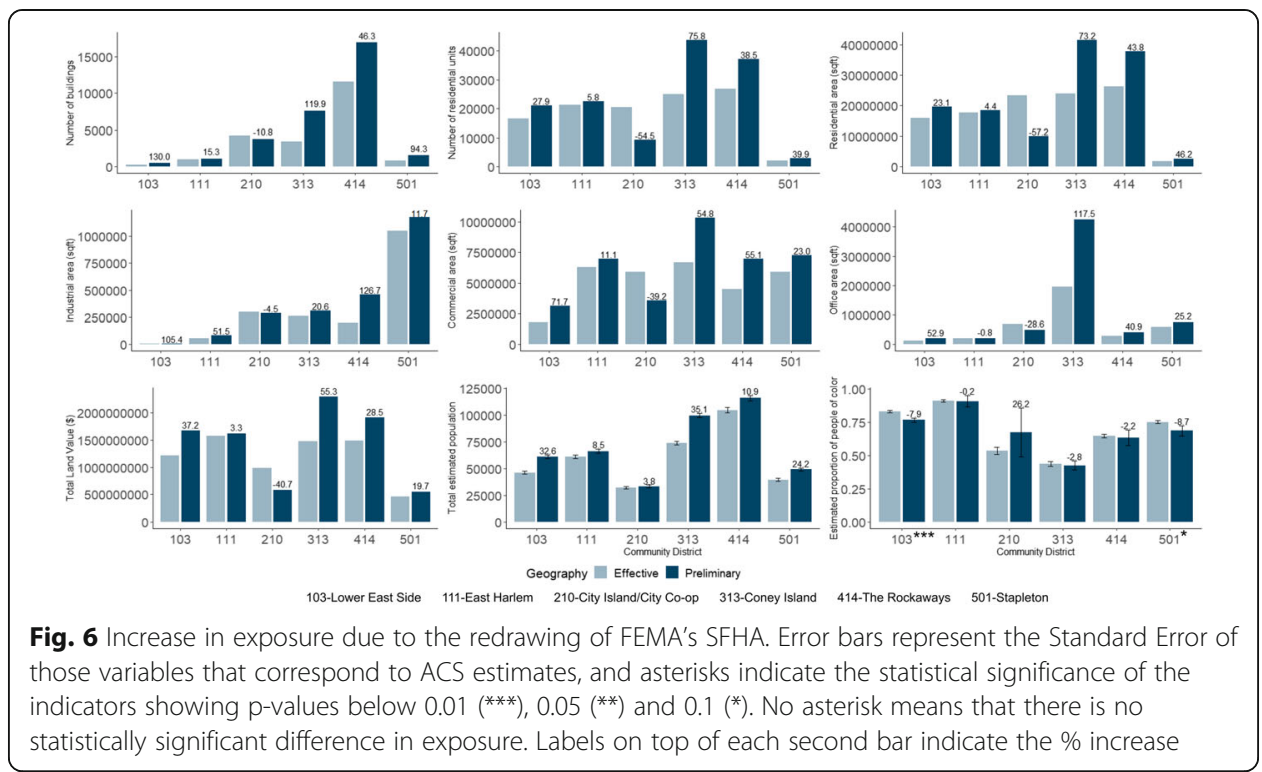

(111) and Stapleton (501), the addition of new area to the preliminary SFHA lead to an increase in exposed industrial land. This increase, however, is minor compared to the decrease in industrial area within the effective SFHA (observed in RQ1). In City Island/ Co-op City (210), industrial area has considerably increased over time within the effective SFHA, but since the floodplain area in this CD is smaller, the redrawing of the floodplain does not affect overall exposure. The addition of vulnerable land uses, such as industrial land use, due to the overall expansion of the floodplain raises important questions about the direction that urban development should take in the immediate surroundings of effective floodplains, which are subject to change and, most likely, to expand.

Increase in land value is also not proportional to the flooded area. For example, in Stapleton (515) land values have increased 19.7\%, while the flooded area doubled. Considerable increases take place in Lower East Side (103, 37.2\%), Coney Island (313, $55.3 \%)$ and the Rockaways $(414,28.5 \%)$, while the increase in the value of the exposed lots in Stapleton (501) shows a limited increase (19.7\%) compared the expansion of the floodplain. This might be related to the high amount of industrial land use that the preliminary floodplain adds. In East Harlem (111), a slight increase (3.3\%) occurs regardless of the reduction in the area flooded, meaning that the lots added to the floodplain have a higher value than those excluded A sharp decrease $(-40.7 \%)$ takes place in City Island/Co-op City (210) due to the removal of the Co-op City development from the floodplain.

The total estimated population exposed to flooding according to the SFHA shows an increase of $10.5 \%$ (from 385,107 to 425,484 ), $52.5 \%$ of the total population in the studied CDs is located on the preliminary SFHA according to the most recent ACS data. The population living in PEJAs and exposed to flood increases by 7.6\% (from 275, 682 to 298,259). The largest relative increases in population happen in Lower East Side (103), a densely built CD, and Coney Island (313). In the Rockaways (414) and Stapleton (501), the increase in the exposed population is relatively small compared to the 
area increase between both floodplains. In Lower East Side (103) and Stapleton (501), statistically significant differences can be observed regarding the proportion of people of color between the population within the effective floodplain and the one added in the preliminary floodplain. In both cases, the population added shows a lower presence of people of color.

Social vulnerability overall exhibits complex patterns, with much of the population added to the floodplain being less vulnerable than that within the effective floodplain (Fig. 7). In Lower East Side (103), six indicators show that the population living in the area added to the floodplain by the preliminary SFHA are less vulnerable than the population living in the effective floodplain. The same trend appears in Coney Island (313), with four indicators, and in Stapleton (501) with three. There are strong exceptions to this trend in East Harlem (111), where the added population has a higher proportion of single parent families, households below the poverty level, and car owners. In addition, median income seems to be lower. This is probably explained by the fact that the vast majority of East Harlem (94.6\%) is considered a PEJA, as Fig. 1 showed.

Are there significant differences in vulnerability between the exposed and the nonexposed populations to the SFHA according to its preliminary update?

Exposed and non-exposed populations have dichotomous patterns of vulnerability between CDs (Fig. 8). Coney Island (313) was excluded from this analysis because all of its census block groups intersect with the preliminary floodplain, meaning almost everyone lives on the floodplain. Stapleton (501) shows the sharpest differences between exposed and non-exposed populations, with seven statistically significant indicators showing that the exposed population is much more vulnerable than the unexposed one. In Lower East Side (103), four indicators depict the same situation. A similar pattern is observed in East Harlem (111) for language isolation, rented households and single parents. In the Rockaways (414), the results are mixed, with some indicators such as rented households, language isolation, and income depicting lower vulnerability in the floodplain. In City Island/Co-op City (210), five indicators show that the overall vulnerability within the floodplain is lower than in the rest of the $\mathrm{CD}$. The results obtained seem to be related to the location of PEJAs in each neighborhood, as well as how particular developments are included or not within the preliminary update to the SFHA (see Fig. 1).

\section{Discussion}

In this study, we aimed to explore how coastal flood risk has changed across time and space, as well as the EJ implications linked to the (re) distribution of flood risk across six different New York City communities. Below, we discuss three key aspects of our study results and implications for policy and future work on flood risk: interactions between drivers, the uneven distribution of vulnerability, and the need for analytical frameworks and policies that address intersectional risk.

\section{Interactions between drivers of flood risk}

Based on the so-called "risk triangle", our study relied on an understanding of risk as the interaction between hazard, exposure and vulnerability. We consider two key 


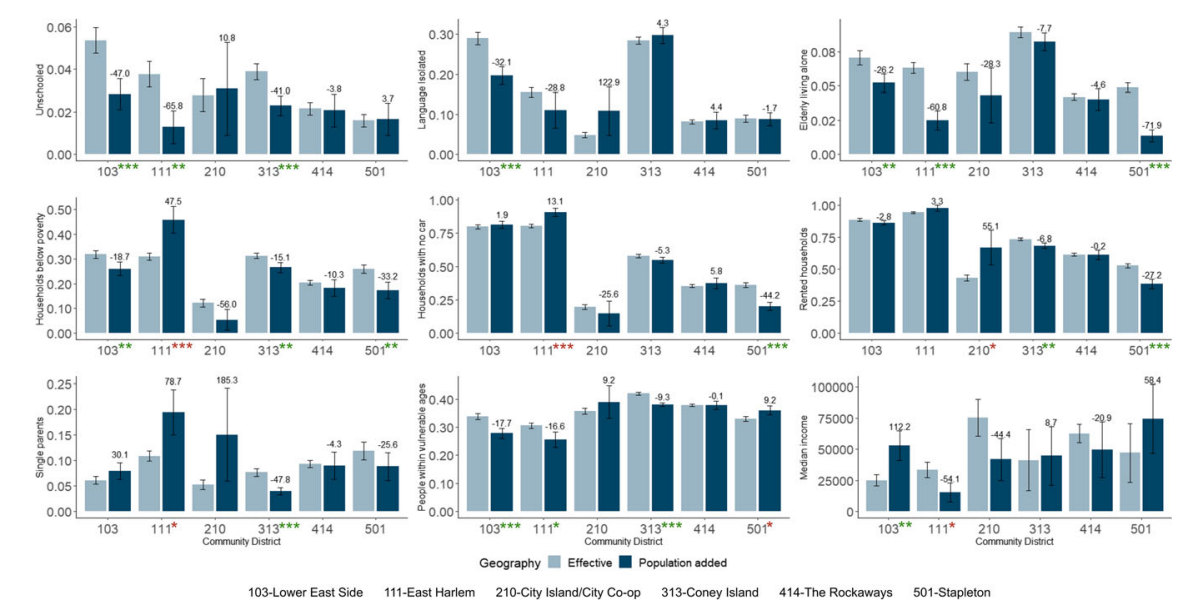

Fig. 7 Differences between the exposed populations according to the effective SFHA and those added due to its redrawing. Error bars represent the Standard Error of those variables that correspond to ACS estimates, and asterisks indicate the statistical significance of the measures compared according to p-values below $0.01\left(^{(* *}\right), 0.05\left(^{* *}\right)$ and $0.1\left(^{*}\right)$. No asterisks mean that there is no statistically significant difference. Red asterisks indicate that the added population is more vulnerable, while green asterisks indicate lower vulnerability. Labels on top of each second bar indicate the \% increase

processes as the main drivers of coastal flood risk. First, the process of urban change (shifts in the built environment and demographics) drives changes in exposure and vulnerability. Second, the redrawing of the 100-year floodplain within FEMA's NFIP affects the hazard component of the triangle by updating the magnitude of the event's impact in terms of extent. It is important to consider that the socio-economic metrics used in this study were developed during the period that followed the 2008 financial crisis, making it a potential driver of change. However, while the socioeconomic consequences of the crash were most acute in its first two years, our study shows that social

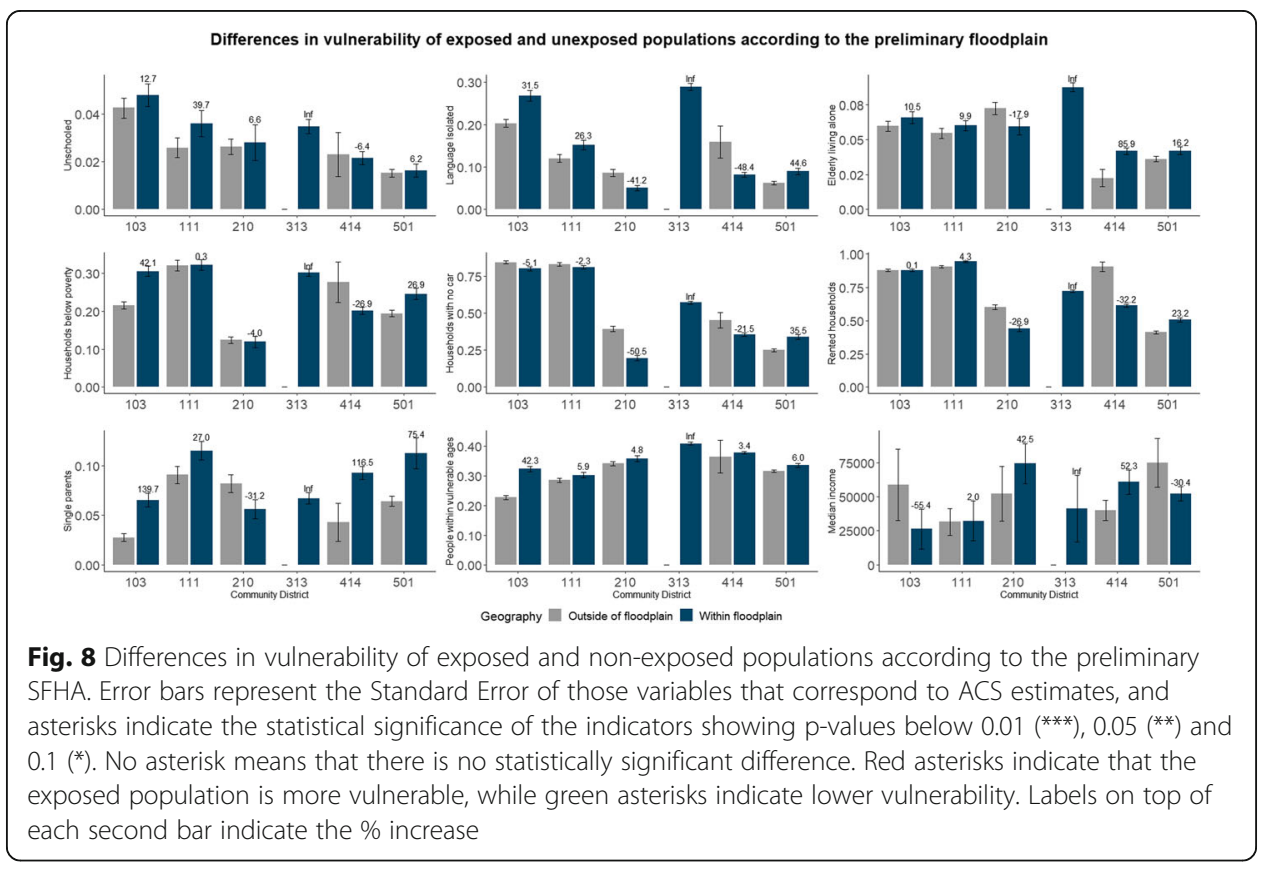


vulnerability increased during the period of recovery that followed (McMahon 2018). Future iterations of this may focus on answering the differential effect of the financial crisis inside and outside of the floodplains.

We find that together these processes continue to increase coastal flood risk in NYC. Here we discuss the major policies affecting ongoing floodplain development, namely, zoning, flood resilience planning, and the existing national flood insurance program (NFIP). These social drivers are closely intertwined with updates to the SFHA and its relationship with observations of sea level rise and increased frequency of extreme weather events.

\section{Policies affecting ongoing floodplain development}

Our analysis shows that coastal flood risk significantly increases due to ongoing development across the studied CDs within the effective floodplain. Population, assets and land use acreages continued to increase in the effective floodplain during the period studied, linking shifts in flood risk to exposure changes. In some of these communities, social vulnerability has increased in addition to development-borne exposure. For example, during the period studied, the Bloomberg administration boosted urban renewal within NYC's waterfront with PlaNYC: A Greener, Greater New York (City of New York 2007). Many other subsequent plans, visions and regulations (NYC Planning 2011a, 2013; NYC City Planning Commission 2013; New York City 2019) have provided the city with a framework to carry out intensive waterfront development, especially in Manhattan and Brooklyn, increasing human and infrastructure exposure.

These plans are linked to changes in land use, built densities, and other aspects of urban form that are regulated through zoning. Zoning in NYC incorporates updated base elevation requirements for buildings based on the preliminary floodplain (Berry and BenDor 2015). However, these types of changes aim to ensure resilient development within the floodplain, without restricting it. As the "safe development paradox" states, there is a danger that a false sense of security can trigger development in areas where risk mitigation measures are only designed to handle events of a certain magnitude and scale (Burby 2006; Stevens et al. 2010). In contrast, the introduction of policy measures such as the Special Coastal Risk Districts and the Resilient Neighborhoods Initiative limited the density of new development in the rezoning of neighborhoods such as Broad Channel and Hamilton Beach in Queens. New residential development was limited to single-family detached homes only and community facilities with sleeping accommodations were prohibited (NYC Planning 2017a). In East shore, in Staten Island, this limitation was combined with the requirement to receive an authorization from the City Planning Commission for any new development and horizontal enlargement (NYC Planning 2017b).

However, not every recent rezoning in NYC has incorporated flood risk mitigation. In East Harlem, a 2017 rezoning project shows commitment to invest in the development of affordable housing in lots that might be highly exposed to flooding (Mayor's Office of Operations 2019). Higher levels of limiting development on the floodplain would require total prohibition of new development. As Stevens et al. (2010) claim, the feared economic consequences of such a decision (e.g.loss of tax revenue, compensations to landowners and developers) should not mask the increasing economic losses 
caused by flood hazards when they hit communities like the ones studied here. However, current federal policy, embodied in the NFIP, subsidizes ongoing floodplain development. This contradiction emerges from FEMA's mandate to safeguard coastal resilience while maintaining coastal property markets, which was key to secure property holders and regulators buy-in to pass the NFIP through Congress. Presently, ratepayers do not provide enough insurance capital to cover potential losses (Horn and Brown 2018), and are likely underestimating the outstanding liabilities due to future flooding (Shively 2017). Taxpayers subsidize the NFIP, thus public money is effectively used to cover private developers' risks. At a more granular level, the flood insurance rates set by the FIRM fundamentally depend upon the representation of flood likelihoods and severity represented by the SFHA, which we address in the following section.

\section{Changes in floodplain extent driving the production of flood risk}

We find that the SFHA in the CDs studied grows in extent by $45.7 \%$ due to the preliminary redrawing. The CDs of Coney Island and the Rockaways show a dramatic increase in the impact that a 100-year event has on them. These results are based on the preliminary floodplain, which is subject to change in the coming years due to its revision. Additionally, in this study we limited the analysis to changes in the extent of the floodplain, future iterations should consider changes in the base flood elevation too as a way of incorporating gradients of risk. Nevertheless, these CDs were severely impacted by Superstorm Sandy, which flooded vast areas outside of their effective floodplain and had a return period of 103 years for its peak water level (Lopeman et al. 2015). Hence, we consider that, at least in the case of Coney Island and Rockaway, the preliminary floodplain does not likely overestimate risk. Other CDs experienced slight reductions in their floodplain extents, such as the $4 \%$ decrease in City Island/Co-op City (210). This seemingly small reduction excludes the 10,000-unit development of Co-op City from the SFHA, waiving the obligation to purchase flood insurance (FEMA 2011). The preliminary SFHA boundary remains $50 \mathrm{~m}$ from buildings within the development, raising important questions about how bounding flood exposure based on a single return period may inappropriately define risk (Ward et al. 2011; Koerth 2017; Kousky 2018). After decades of reliance on the 100-yr floodplain designation, the NFIP is expected to experience a deep transformation in October 2021 with the expected adoption of Risk Rating 2.0. This transformation aims to make it easier and fairer to assess flood risk at the property level by incorporating technological advances and updated understandings of flood risk (FEMA 2019). Still, the details of how risk will be assessed is unclear. Furthermore, changes in flood risk assessment methods may be limited if future risk due to climate change remains unassessed, limiting the consideration of non-stationary risks in current urban planning processes (Pralle 2019).

The change in hazard probability as represented by the SFHAs' redrawing of the 100year floodplain is just one framing of flood risk defined by a largely technical knowledge system process. The outcome of the decisions made at each step of this process reshape life on USA's waterfronts by determining the enforcement of the NFIP, and are often sharply contested by local communities and developers (Pralle 2019). These contestations often center on the financial impacts of mandatory flood insurance on 
low income households, as well as the ability of developers to sell floodplain real estate. In NYC, the ongoing contestation of the SFHA leaves significant numbers of residents, which in our study represented a $\sim 10 \%$ increase in the flood exposed population, uncertain as to whether they should purchase flood insurance. Due to this lack of a clear understanding of their risk, some homeowners have given up the policies they voluntarily purchased after their homes were damaged by Sandy (Choi et al. 2019).

While these social contestations are ongoing, climate change and sea level rise will likely continue to increase coastal flooding frequency and severity within the region (Sallenger et al. 2012; Orton et al. 2016). The NPCC's (New York City Panel on Climate Change) projected 100-year floodplain for 2050 has a very similar area to the current 500-year floodplain, roughly corresponding to Superstorm Sandy's highwater line. Thus, recent extreme weather events may be the new normal under climatic conditions anticipated by the NPCC, and as our discussion of the NFIP, zoning, and resilience planning emphasizes, current programs of flood response and waterfront development continue to exacerbate the underlying drivers of risk with uneven social consequences.

\section{Uneven distributions of vulnerability to flood risk}

Overall, we find that flood risk is distributed unevenly in the community districts studied. The current distribution of unevenly vulnerable communities across NYC is the result of complex histories of urban development on New York City's coastline, where land was cheaper, and many of the city's public housing projects were erected from the 1940 s to the 1960s. A major reason why land was cheap was due to practices of redlining which deeply intertwined racist geographies of real estate investment (Aalbers 2014) with the delineation of the floodplain through the 1930s (Nelson et al. n.d.) Low prices of land in turn as well as access to infrastructure, facilitated the development of coastline industries and associated environmental contamination. Thus, race and class remain embedded within three major dimensions of EJ affecting the distribution of vulnerability to flood risk, namely the patterns of renting and home ownership, public housing, and the distribution of environmental hazards.

\section{Housing markets, home ownership and locational benefits}

NYC's historical legacy of segregation has affected homeownership rates of people of color by denying access to mortgages and financial capital. Today, in boroughs like Queens and Brooklyn, low homeownership rates among people of color persist, as do higher rates of foreclosures and barriers to refinancing, reflected by higher rates of needed home repairs (Baker et al. 2018). These racial and income differences are rooted in historical zoning laws and redlining, policies creating decades of systematic underinvestment in areas where largely immigrants and people of color lived, as well as flood zones. Various degrees of redlining happened in all the PEJAs we studied (Nelson et al. n.d.). Even when people of color own homes, they may face continued vulnerability due to structural inequities in labor markets and incomes. Combined with increasing prices of flood insurance premiums and prohibitively expensive flood-resilient retrofits, some homeowners of color are presently at higher risk of displacement from floodplain areas, further worsening the homeownership and racial wealth gaps that exist in the city (Paganini 2019). Additionally, redlining may have also led to higher levels of rentership 
among people of color by limiting intergenerational wealth transfer among discriminated groups (Jones 2017). Development and gentrification patterns, especially in the Lower East Side and East Harlem, complicate this picture as economic upscaling and neighborhood deterioration thrive side by side (Goldstein 2017). Historical and current factors depressing housing value and reducing housing access must therefore be considered alongside patterns of specifying zones of increased real estate values, often driven by perceived or real amenity value.

The amenity value of floodplains is derived from the perceived locational benefits driving coastal development, reflected in higher than average real estate values in floodplains that have other desirable attributes. For instance, sales inventories and recorded sales have dramatically increased in areas hit by Hurricane Sandy (Quintana 2017; Erdos 2018) also fueled by newly developed ferry routes. New high-end developments have increased home values in wealthy beachfront properties, as well as in lower income areas like Far Rockaway, triggering concerns over housing affordability and displacement.

An analysis of amenity value will be necessary to understand counter-intuitive patterns of social vulnerability within the CDs studied. In the case of City Island/Co-op City (210) and, to a lower degree, Rockaway (414), more affluent floodplain residents have lower socio-economic vulnerability than non-floodplain residents. Moreover, although the Bronx is the poorest in the nations' 435 congressional districts (DiNapoli and Bleiwas 2018a), some of its coastal areas are also home to some affluent and middle-class communities, including Pelham Bay, City Island and Co-op City. These areas also count with a higher concentration of amenities such as shopping, recreational districts, and parks. This situation mirrors what Collins et al. (2018:319) observed in the case of Miami and Houston, in that there exist counterintuitive patterns in social exposure to flood risk driven by the "...indivisibility of amenity values from high risk landscapes".

Recognizing the importance of amenity value also highlights the relationship between resilience planning and real estate value. For example, the North shore is Staten Island's poorest neighborhood, where development was restricted in 2004 (NYC Planning 2004), and yet has recently seen large increases in property rents and value. In 2011, the City proposed several waterfront redevelopment projects as part of North Shore 2030 (NYC Planning 2011b). Such projects are designed to improve landscaping for stormwater reduction, bulkheads and shoreline, as well as abiding to building code limitations. However, these efforts could jeopardize housing affordability in the long run (DuPuis and Greenberg 2019) in an area where a third of the families face severe rent burden, devoting 50\% of their income on rent (DiNapoli and Bleiwas 2018b).

\section{Public housing}

The share of public housing in each community district is also an important driver of vulnerability. We found higher vulnerability of populations exposed to the floodplain in Lower East Side, Stapleton and East Harlem, districts with high concentrations of public housing in the floodplain. For instance, Lower East Side has 26 public housing developments with more than 30,000 residents, nine owned by the NYC Housing Authority (NYCHA), exposing 21,000 low income and predominantly people of color 
to the floodplain (NYU Furman Center 2019). The Lower East Side has similar racial and economic characteristics as Rockaway, and has also been characterized by a process of gentrification with decreasing home ownership and growing rents (NYU Furman Center 2018). Earlier events further demonstrate increased vulnerability of public housing residents as prior work found that six NYCHA owned public housing properties had no running water, heat, or repair work done on their houses long after Hurricane Sandy (Graham et al. 2016). Seven years after the hurricane, repair work funded by FEMA had only been completed in 2 of the 200 damaged NYCHA buildings (Aponte and Smith 2019). FEMA only agreed to finance repair work for flood related damage, leaving out critical renovations on long-standing leaks and mold issues across NYCHA developments (Kasakove and Williams 2019) that may have an effect on the overall resilience of its residents.

\section{Environmental hazards}

Besides public housing and homeownership, environmental pollution makes up a more complex understanding of vulnerability in coastal areas. The PEJAs in our study contain contaminated sites and toxic facilities, exposing the linkages between land use and zoning and the disproportionate environmental burdens in low-income or communities of color. For instance, in East Harlem, there are 25 records of Open Spills, 171 registrations of Petroleum Bulk Storage (PBS) and 96 sites where the presence of hazardous pollutants requires an environmental impact assessment (Planning 2016). Stapleton's north shore hosts a Significant Maritime and Industrial Area (SMIA), including 5.2 mile $^{2}$ declared as contaminated by the U.S. Environmental Protection Agency. All of the SMIA's polluted sites are located within $70 \mathrm{ft}$ from homes (Checker 2009). Might the defensive infrastructure fail during a flooding event, the impact of the flooding would escalate due to the combination of water with hazardous pollutants.

Although the NYC Mayor's Special Initiative for Rebuilding and Resilience (SIRR) and the Hurricane Sandy Rebuilding Task Force did not adequately address the EJ consequences of SMIAs (Sandy Regional Assembly 2013), the 2019 Climate Leadership and Community Protection Act (CLCPA) contains several EJ provisions (Morris and Farmer 2019). The result of efforts by 180 environmental, community and labor organizations, the CLCPA includes a target for disadvantaged communities to receive $35 \%$ of the benefits from the state's climate programs, the creation of a Climate Justice Working Group, a community Air Monitoring Program and a requirement for the state to prioritize projects that both reduce GHG emissions and eliminate criteria pollutants in historically disadvantaged communities.

EJ consequences are also tied to New York City's infrastructure system in the floodplain. For instance, in West Rockaway sewage overflow from the Rockaway Wastewater Treatment Plant in Rockaway West and the two pumping stations in Rockaway East mixed with Hurricane Sandy flood waters and seeped into homes, creating a polluted mix that lingered for weeks (Rockaway West Planning Committee 2013). FEMA approved investments to repair the plant, but in 2018 it was still relying on generators for power. The cascading effects of power infrastructure failures are well known (Serre and Heinzlef 2018) and may exacerbate existing inequalities in the ability of people to pay for their home remediation if action is not taken at multiple-scales. 
The social vulnerability patterns of flood risk in New York City's floodplains are inextricably linked with long standing racialized geographies in waterfront communities. Existing patterns of home ownership and rentals, the distribution of public housing and environmental pollution in the floodplain will likely continue to be exacerbated by future storm events. Environmental governance and climate resilience programs by the state and local government need to embed explicit provisions addressing such disparities.

\section{Towards analysis and policies addressing contextual flood risk}

Our analysis indicates coastal flood vulnerability in NYC is highly uneven, with some vulnerable communities increasing in flood exposure, while other areas experiencing increasing development despite increasing flood risks. These results highlight complex interdependencies between the social processes of representing flood risks, the uneven consequences of being flooded, and the palette of responses available to manage flooding. Future work on coastal flooding should utilize a concept of risk that includes vulnerability, pays attention to the procedures shaping the distributions of flood risk and vulnerability, and guides more just processes for reducing flood risks.

Social, ecological, technological systems (SETS) frameworks clarify connections across social, environmental, and technical dimensions, including the relationships between representations of complex urban systems and the social processes that seek to transform them (McPhearson et al. 2016; Grabowski et al. 2017; Markolf et al. 2018). These urban systems conceptual framework focuses on interdependencies across social, ecological, and technological domains of cities and can help to emphasize urban transformation and processes of knowledge generation, allowing us to consider how the distribution of flood risk is inseparable from the flood knowledge system. Within such a framework, we can tie improved biophysical knowledge about current and future flood risks and technical processes for deciding on flood adaptation pathways, with a more nuanced understanding of social vulnerability. While our analysis has emphasized the potential uneven consequences of flood risks, our discussion emphasizes the social processes shaping outcome vulnerability, a form of 'contextual vulnerability.' Contextual vulnerability approaches emphasize that vulnerability is not just determined by sensitivity to outcomes of undesirable events, such as climate related coastal flooding, but is a product of the processes defining, managing, and producing vulnerability (O'Brien et al. 2007). A contextual lens reinforces the idea that the social and spatial distribution of flood risk cannot be separated from longer running EJ concerns over procedural equity, in particular within the institutional processes shaping how flood related infrastructure investments are prioritized. Presently, embedded inequalities in infrastructure decision-making may lead to more socially powerful actors receiving a disproportionate share of flood mitigation resources or benefitting from increasing property values. Within the CDs studied, this appears to be the case in Far Rockaway, where procedural inequity overlaps with distributional inequities in post-hurricane infrastructure efforts. For example, the $\$ 341$ million boardwalk funded by FEMA, opened in 2017, benefitted property values of largely white homeowners, while predominantly black renters lacked the economic means to meet FEMA's criteria for assistance (Erdos 2018). 
More just policy responses should address zones of double jeopardy, defined by areas of low housing value that concentrates lower income residents in flood prone areas. Current policy mechanisms focusing on building codes and flood proofing not only can lead to housing displacement, but also increase asset exposure in the long term. Addressing floodplain gentrification and double jeopardy in the flood zone thus must be addressed by changes elsewhere in the urban system, namely through building accessible and public housing outside of the floodplain. The fact that the NFIP relies upon public funds from the U.S. Treasury to cover the losses of private individuals, and coastal flood protection at large increasingly demands public investments in infrastructure, makes clear that flood adaptation is a matter of public policy requiring greater procedural openness and transparency for more equitable outcomes.

Ultimately flood risks go beyond the flood zone by affecting networked critical infrastructure systems and shifting the overall demand for different land uses. While we, like many others, focus on exposure within probabilistic flood boundaries, future work must examine how the interdependent risks of critical infrastructure failures due to flooding can be addressed simultaneously with improved policies around housing affordability, managed retreat, and supporting equitable wealth generation through improved public infrastructures. Going forward, communities, policymakers, planners, and developers need to think more expansively about multiple social, environmental, and infrastructural drivers of flood risks at the scale of the whole city and the region. Future work should examine the equity of current flood adaptation and mitigation pathways and identify best practices for cooperative risk reduction that addresses the concerns of all impacted communities.

\section{Conclusions}

Coastal flood risk in NYC continues to increase due to ongoing floodplain development and population growth, is likely to further increase with floodplain expansion, and impacts both vulnerable communities forced into contaminated and less desirable housing areas as well as developments seeking to attract affluent residents with coastal amenity values. At the same time, significant increases in potentially flooded areas driven by sea level rise and climate change intersect with the complex technical and social processes of anticipating and responding to coastal flooding risks. Currently, flood resilience programs have sought to maintain development in coastal zones by focusing on site and community level infrastructure interventions that can mitigate anticipated flood impacts. Longer term, the rate at which sea level continues to rise, and its accompanying significant biophysical (the rate of glacial and sea ice loss combined with rates of ocean warming) and political uncertainties (how and who ultimately will have the final word in redrawing NYC's SFHA), will determine the success of those interventions. While the appeal of the city against the preliminary SFHA makes clear the desire of developers and homeowners to avoid the costs of mandatory flood insurance, the updated preliminary SFHA represents a tentative expansion of the 1 in 100-year floodplain, and should be seen as highly conservative given the realities of rising sea levels and more likely extreme weather events. At the same time, many vulnerable residents already 
reside within the effective floodplain, making it clear that when the floods return, their social consequences will be highly uneven. The question of which populations can continue living in the floodplain is an EJ question. What NYC urgently needs is an approach towards coastal management that addresses the paradox of luxury coastal development and highly vulnerable coastal zones, and one informed by the best available science and an attention to social and EJ.

\section{Abbreviations}

NYC: New York City; EJ: Environmental justice; FEMA: Federal Emergency Management Agency; SFHA: Special Flood Hazard Area; NFIP: National Flood Insurance Program; RQ: Research question; CD: Community District; PEJA: Potential Environmental Justice Area; PLUTO: Primary Land Use Tax Lot Output; ACS: American Community Survey; NYCHA: New York City Housing Association; SMIA: Significant Maritime and Industrial Area; ERPA: East River Park Action Group; NPCC: New York City Panel on Climate Change

\section{Acknowledgements}

The authors thank Claudia Tomateo for providing valuable advice for improving the quality and narrative of the figures presented in this paper. The authors also thank the anonymous reviewer(s) that reviewed this manuscript for their valuable comments, as well as this journal for making the publication possible.

\section{Authors' contributions}

Pablo Herreros co-designed the research questions, methods, conducted core analysis, and lead the writing. Veronica Olivotto, Zbigniew Grabowski, and Timon McPhearson co-designed the methods, the paper's framing, and contributed significantly to writing of the manuscript. The authors read and approved the final manuscript.

\section{Funding}

Research was supported by the US National Science Foundation through the Urban Resilience to Extreme WeatherRelated Events Sustainability Research Network (NSF grant no. SES 1444755), as well as the US NSF Accel-Net program NATURA (grant no. 1927167), and US NSF Convergence program (grant no. 1934933). Research was also partially funded through the 2015-2016 BiodivERsA COFUND call for research proposals, with the national funders the Swedish Research Council for Environment, Agricultural Sciences, and Spatial Planning; the Swedish Environmental Protection Agency; the German Aerospace Center; the National Science Centre, the Research Council of Norway; and the Spanish Ministry of Economy and Competitiveness. Support for TM was provided by by NordForsk through funding to the SMARTer Greener Cities project (95377)

\section{Availability of data and materials}

Not applicable.

\section{Competing interests}

The authors declare no conflict of interests arose during the development of this research.

\section{Author details}

${ }^{1}$ Urban Systems Lab, The New School, New York, NY, USA. ${ }^{2}$ Milano School of Policy, Management and the Environment, The New School, New York, NY, USA. ${ }^{3}$ Cary Institute of Ecosystem Studies, Millbrook, NY, USA.

${ }^{4}$ Stockholm Resilience Centre, Stockholm University, Stockholm, Sweden.

Received: 23 January 2020 Accepted: 8 July 2020

Published online: 29 July 2020

\section{References}

Aalbers MB. Do maps make geography? Part 1: redlining, planned shrinkage, and the places of decline. ACME: An International Journal for Critical Geographies. 2014;13:525-56.

Aponte Cl, Smith GB. NYCHA's post-Sandy rebuild mired in delays and dubious contracts. In: The City; 2019. https://www. thecity.nyc/special-report/2019/10/29/21210733/nycha-s-post-sandy-rebuild-mired-in-delays-and-dubious-contracts. Accessed 1 Jun 2020.

Baker J, Goldberg L, Nagy C, Perez I. Aftermath: affordable homeownership in new York City; 2018. Center for NYC Neighborhoods.

Berry M, BenDor TK. Integrating Sea level rise into development suitability analysis. Comput Environ Urban Syst. 2015;51:1324. https://doi.org/10.1016/j.compenvurbsys.2014.12.004.

Brown S, Nicholls RJ, Goodwin P, et al. Quantifying land and people exposed to sea-level rise with no mitigation and $1.5^{\circ} \mathrm{C}$ and $2.0^{\circ} \mathrm{C}$ rise in global temperatures to year 2300. Earth's Future. 2018;6:583-600. https://doi.org/10.1002/2017EF000738.

Buckley C (2013) Twice as many structures in FEMA's redrawn flood zone. The New York Times.

Bullard RD, Wright B. Race, place, and environmental justice after hurricane Katrina: struggles to reclaim, rebuild, and revitalize New Orleans and the Gulf coast. Colorado: Perseus Books; 2009. https://books.google.com/books?hl=en\&lr=\&id= bynRDQAAQBAJ\&oi=fnd\&pg=PR\&\&dq=Race,+place,+and+environmental+justice+after+hurricane+Katrina:+struggles+to+ reclaim,+rebuild,+and+revitalize+New+Orleans+and+the+Gulf+coast:+Perseus+Books\&ots=_hZlhfnGG8\&sig= HHVTwRyZSPW3mJDXbKGHmqLO2tQ\#.

Burby RJ. Flood insurance and floodplain management: the US experience. Global Environmental Change Part B: Environmental Hazards. 2001;3:111-22. https://doi.org/10.3763/ehaz.2001.0310. 
Burby RJ. Hurricane Katrina and the paradoxes of government disaster policy: bringing about wise governmental decisions for hazardous areas. The ANNALS of the American Academy of Political and Social Science. 2006;604:171-91. https://doi. org/10.1177/0002716205284676.

Camarasa-Belmonte AM, Soriano-García J. Flood risk assessment and mapping in peri-urban Mediterranean environments using hydrogeomorphology. Application to ephemeral streams in the Valencia region (eastern Spain). Landsc Urban Plan. 2012;104:189-200. https://doi.org/10.1016/.landurbplan.2011.10.009.

Chakraborty J, Collins TW, Grineski SE. Exploring the environmental justice implications of hurricane Harvey flooding in greater Houston, Texas; 2019. https://doi.org/10.2105/AJPH.2018.304846. http://ajph.aphapublications.org/. Accessed 15 Jan 2020.

Chakraborty J, Collins TW, Montgomery MC, Grineski SE. Social and spatial inequities in exposure to flood risk in Miami. Florida Natural Hazards Review. 2014;15:2005-20.

Chakraborty J, Maantay JA, Brender JD. Disproportionate proximity to environmental health hazards: methods, models, and measurement; 2011. https://doi.org/10.2105/AJPH.2010.300109. http://ajph.aphapublications.org/. Accessed 15 Jan 2020

Checker M. Staten Island's toxic Stew: Gotham Gazette; 2009. https://www.gothamgazette.com/environment/227-statenislands-toxic-stew. Accessed 1 Jun 2020

Chen DW (2018) In New York, Drawing Flood Maps Is a 'Game of Inches.' The New York Times.

Choi A, Chung C, Smith GB. Flirting with disaster: flood zones still uninsured years after Sandy: The City; 2019. http://thecity. nyc/2019/10/nyc-flood-zones-still-uninsured-years-after-superstorm-sandy.html. Accessed 21 May 2020.

City of New York. PlaNYC: a greener, greater New York; 2007. The City of New York, New York, NY, USA.

City of New York. PlaNYC: a stronger, more resilient New York; 2013. The City of New York, New York, NY, USA.

Collins MB, Munoz I, JaJa J. Linking 'toxic outliers' to environmental justice communities. Environ Res Lett. 2016;11:015004. https://doi.org/10.1088/1748-9326/11/1/015004.

Collins TW, Grineski SE, Chakraborty J. Environmental injustice and flood risk: a conceptual model and case comparison of metropolitan Miami and Houston, USA. Reg Environ Chang. 2018;18:311-23. https://doi.org/10.1007/s10113-017-1121-9.

Colten CE. Environmental justice in a landscape of tragedy. Technol Soc. 2007;29:173-9. https://doi.org/10.1016/j.techsoc. 2007.01.006.

Comes T, de Walle BV. Measuring disaster resilience: the impact of hurricane Sandy on critical infrastructure systems. In: Proceedings of the 11th international ISCRAM conference 10; 2014.

Crichton D. The risk triangle. Natural disaster management; 1999. p. 102-3.

de Moel $\mathrm{H}$, Aerts J JJH. Effect of uncertainty in land use, damage models and inundation depth on flood damage estimates. Nat Hazards. 2011;58:407-25. https://doi.org/10.1007/s11069-010-9675-6.

Depietri Y, McPhearson T. Changing urban risk: 140 years of climatic hazards in new York City. Clim Chang. 2018;148:95-108. https://doi.org/10.1007/s10584-018-2194-2.

DiNapoli TP, Bleiwas KB. An economic snapshot of the Bronx; 2018a. State of New York Comptroller.

DiNapoli TP, Bleiwas KB. An economic snapshot of Staten Island; 2018b. State of New York Comptroller.

Dixon L, Clancy N, Bender B, et al. Flood Insurance in new York City Following Hurricane Sandy; 2013. https:/www.rand.org/ pubs/research_reports/RR328.html. Accessed 15 Jan 2020.

DuPuis EM, Greenberg M. The right to the resilient city: progressive politics and the green growth machine in new York City. J Environ Stud Sci. 2019;9:352-63. https://doi.org/10.1007/s13412-019-0538-5.

Elliott R. 'Scarier than another storm': values at risk in the mapping and insuring of US floodplains. Br I Sociol. 2019;70:106790. https://doi.org/10.1111/1468-4446.12381.

Enman S. Outdated federal flood maps leave residents at risk, experts say: Brooklyn Eagle; 2019. https://brooklyneagle.com/ articles/2019/10/30/outdated-federal-flood-maps-leave-residents-at-risk-experts-say/. Accessed 15 Jan 2020.

Erdos E. Hurricane Sandy and the inequalities of resilience in New York: The American Prospect; 2018. https://prospect.org/ api/content/83b3277e-3773-5458-9cc8-692b84f3edbd/. Accessed 1 Jun 2020.

Faber JW. Superstorm Sandy and the demographics of flood risk in new York City. Hum Ecol. 2015;43:363-78. https://doi.org/ 10.1007/s10745-015-9757-x.

FEMA. Flood insurance study. Washington: Federal Emergency Management Agency; 2007.

FEMA. Answers to questions about the NFIP; 2011.

FEMA. Flood insurance study. Washington: Federal Emergency Management Agency; 2013.

FEMA. View your Community's preliminary flood Hazard data; 2019a. https://www.fema.gov/view-your-communityspreliminary-flood-hazard-data. Accessed 22 Apr 2020.

FEMA (2019b) NFIP transformation and risk rating 2.0 | FEMA.gov. https://www.fema.gov/nfiptransformation. Accessed 1 Jun 2020.

FEMA (2020) Letter of map changes | FEMA.gov. https://www.fema.gov/letter-map-changes. Accessed 28 May 2020

FEMA. FEMA flood map service center; n.d. https://msc.fema.gov/portal/home. Accessed 15 Jan 2020.

Freudenberg R, Calvin E, Tolkoff L, Brawley D. Buy-in for buyouts: the case for managed retreat from flood zones. Cambridge: Lincoln Institute of Land Policy; 2016.

Garner AJ, Mann ME, Emanuel KA, et al. Impact of climate change on new York City's coastal flood hazard: increasing flood heights from the preindustrial to 2300 CE. Proc Natl Acad Sci. 2017;114:11861-6.

Goldstein BD. The roots of urban renaissance: Harvard University Press; 2017.

Grabowski ZJ, Matsler AM, Thiel C, et al. Infrastructures as socio-eco-technical systems: five considerations for interdisciplinary dialogue. J Infrastruct Syst. 2017;23:02517002. https://doi.org/10.1061/(ASCE)|S.1943-555X.0000383.

Graham L, Debucquoy W, Anguelovski I. The influence of urban development dynamics on community resilience practice in new York City after superstorm Sandy: experiences from the lower east side and the rockaways. Glob Environ Chang. 2016;40:112-24. https://doi.org/10.1016/j.gloenvcha.2016.07.001.

Grineski S, Collins TW, Chakraborty J, Montgomery M. Hazardous air pollutants and flooding: a comparative interurban study of environmental injustice. GeoJournal. 2015;80:145-58. https://doi.org/10.1007/s10708-014-9542-1.

Horn DP, Brown JT. Introduction to the National Flood Insurance Program (NFIP); 2018. p. 29.

Howell J, Elliott JR. As disaster costs rise, so does inequality. Socius. 2018;4:2378023118816795. https://doi.org/10.1177/ 2378023118816795 
Jones J. The racial wealth gap: how African-Americans have been shortchanged out of the materials to build wealth: Economic Policy Institute; 2017. https:/www.epi.org/blog/the-racial-wealth-gap-how-african-americans-have-beenshortchanged-out-of-the-materials-to-build-wealth/. Accessed 1 Jun 2020.

Kasakove S, Williams T. Is new York City's public housing ready for the next storm? 2019

Kaźmierczak A, Cavan G. Surface water flooding risk to urban communities: analysis of vulnerability, hazard and exposure. Landsc Urban Plan. 2011;103:185-97. https://doi.org/10.1016/j.landurbplan.2011.07.008.

Koerth M. It's time to ditch the concept of '100-year floods: FiveThirtyEight; 2017. https://fivethirtyeight.com/features/its-timeto-ditch-the-concept-of-100-year-floods/. Accessed 15 Jan 2020.

Koks EE, Jongman B, Husby TG, Botzen WJW. Combining hazard, exposure and social vulnerability to provide lessons for flood risk management. Environ Sci Pol. 2015;47:42-52. https://doi.org/10.1016/j.envsci.2014.10.013.

Kousky C. Why Americans are in the dark about flood risks: CityLab; 2018. https://www.citylab.com/environment/2018/10/ how-america-fails-communicating-flood-risks/572620/. Accessed 15 Jan 2020.

Landrigan PJ, Fuller R, Acosta NJR, et al. The lancet commission on pollution and health. Lancet. 2018;391:462-512. https:// doi.org/10.1016/S0140-6736(17)32345-0.

Lopeman M, Deodatis G, Franco G. Extreme storm surge hazard estimation in lower Manhattan. Nat Hazards. 2015;78:355-91. https://doi.org/10.1007/s11069-015-1718-6.

Maantay J, Maroko A. Mapping urban risk: flood hazards, race, \& environmental justice in New York. Appl Geogr. 2009:29:11124. https://doi.org/10.1016/j.apgeog.2008.08.002.

Markolf SA, Chester MV, Eisenberg DA, et al. Interdependent infrastructure as linked social, ecological, and technological systems (SETSs) to address lock-in and enhance resilience. Earth's Future. 2018;6:1638-59. https://doi.org/10.1029/ 2018 EF000926.

Mayor's Office of Operations. NYC rezoning commitments tracker; 2019. http://morr.maps.arcgis.com/apps/MapSeries/index. html?appid=e53a9d13cad442829c5db6c7bc1b16d8. Accessed 1 Jun 2020.

McGhee DJ, Binder SB, Albright EA. First, do no harm: evaluating the vulnerability reduction of post-disaster home buyout programs. Natural Hazards Review. 2019;21:05019002.

McMahon EJ. New York's uneven economic recovery: Empire Center for Public Policy; 2018. http://empirecenter.org/ publications/new-york-uneven-economic-recovery/. Accessed 1 Jun 2020.

McPhearson T, Haase D, Kabisch N, Gren $\AA$. Advancing understanding of the complex nature of urban systems. Ecol Indic. 2016;70:566-73. https://doi.org/10.1016/j.ecolind.2016.03.054.

Morris J, Farmer M. Unpacking New York's big new climate bill: a primer: NRDC; 2019. https://www.nrdc.org/experts/milesfarmer/unpacking-new-yorks-big-new-climate-bill-primer-0. Accessed 1 Jun 2020.

Nelson RK, Winling L, Marciano R, Connolly N. Mapping inequality. In: Mapping inequality. Redlining in new Deal America. https://dsl.richmond.edu/panorama/redlining/\#loc=12/40.858/-73.901\&maps=0\&city=bronx-ny\&text=downloads. Accessed 22 Oct 2019.

Neria Y, Shultz JM. Mental health effects of hurricane Sandy: characteristics, potential aftermath, and response. JAMA. 2012; 308:2571-2. https://doi.org/10.1001/jama.2012.110700.

New York City. OneNYC 2050: building a strong and Fair City - full report 354; 2019.

NYC City Planning Commission. Report: N 130331 (a) ZRY. New York: NYC Planning; 2013.

NYC Planning. Lower density growth management 19; 2004.

NYC Planning. Vision 2020: New York City Comprehensive waterfront plan. New York: NYC Planning; 2011a. https://www1 nyc.gov/site/planning/plans/vision-2020-cwp/vision-2020-cwp.page.

NYC Planning. Chapter 6 | zoning resolution; 2011b. https://zr.planning.nyc.gov/index.php/article-xi/chapter-6. Accessed 1 Jun 2020.

NYC Planning. Urban waterfront adaptive strategies; 2013. https://www1.nyc.gov/site/planning/zoning/amendment-index. page.

NYC Planning. Info brief - flood insurance; 2016.

NYC Planning. Resilient Neighbohoods - old Howard Beach Hamilton Beach Broad Channel - DCP; 2017a. https://www1.nyc. gov/site/planning/plans/resilient-neighborhoods/old-howard-beach-hamilton-beach-broad-channel.page. Accessed 1 Jun 2020.

NYC Planning. Resilient Neighbohoods - east shore - DCP; 2017b. https://www1.nyc.gov/site/planning/plans/resilientneighborhoods/east-shore.page. Accessed 1 Jun 2020.

NYC Planning. NYC Planning ZoLa; n.d.-a https://zola.planning.nyc.gov/about\#9.72/40.7125/-73.733. Accessed 15 Jan 2020a.

NYC Planning. Bytes of the BIG APPLE - archive; n.d.-b https://www1.nyc.gov/site/planning/data-maps/open-data/bytesarchive.page? sorts [year] $=0$. Accessed 15 Jan 2020b.

NYS Department of Environmental Conservation. Commissioner policy 29, environmental justice and permitting - NYS Dept. of environmental conservation; 2003. https://www.dec.ny.gov/regulations/36951.html. Accessed 15 Jan 2020.

NYU Furman Center. State of new York City's housing and neighborhoods in 2018; 2018. NYU Furman Center.

NYU Furman Center. How NYCHA preserves diversity in New York's changing neighborhoods; 2019. NYU Furman Center.

O'Brien K, Eriksen S, Nygaard LP, Schjolden A. Why different interpretations of vulnerability matter in climate change discourses. Clim Pol. 2007;7:73-88. https://doi.org/10.1080/14693062.2007.9685639.

Orton PM, Hall TM, Talke SA, et al. A validated tropical-extratropical flood hazard assessment for New York Harbor. Journal of Geophysical Research: Oceans. 2016;121:8904-29. https://doi.org/10.1002/2016JC011679.

Paganini Z. Underwater: resilience, racialized housing, and the national flood insurance program in Canarsie, Brooklyn. Geoforum. 2019;104:25-35. https://doi.org/10.1016/j.geoforum.2019.06.003.

Planning NYC. Place-based community brownfield Planning Foundation report on existing conditions. Easth Harlem: Mayor's Office of Environmental Remediation; 2016.

Pralle S. Drawing lines: FEMA and the politics of mapping flood zones. Clim Chang. 2019;152:227-37. https://doi.org/10.1007/ s10584-018-2287-y.

Quintana M. Hurricane Sandy NYC: City builds where floods hit hardest | StreetEasy: StreetEasy Blog; 2017. https://streeteasy. com/blog/hurricane-sandy-nyc-five-years-later-city-builds-where-floods-hit-hardest/. Accessed 1 Jun 2020

Rockaway West Planning Committee. Rockaway west community reconstruction conceptual plan; 2013. 
Rohde D. The hideous inequality exposed by hurricane Sandy: The Atlantic; 2012. https://www.theatlantic.com/business/ archive/2012/10/the-hideous-inequality-exposed-by-hurricane-sandy/264337/. Accessed 26 Apr 2020.

Rozance MA, Denton A, Marissa Matsler A, et al. Examining the scalar knowledge politics of risk within coastal sea level rise adaptation planning knowledge systems. Environ Sci Pol. 2019;99:105-14. https://doi.org/10.1016/j.envsci. 2019.05.024.

Sallenger AH, Doran KS, Howd PA. Hotspot of accelerated sea-level rise on the Atlantic coast of North America. Nat Clim Chang. 2012;2:884-8. https://doi.org/10.1038/nclimate1597.

Sandy Regional Assembly. Recovery agenda; 2013.

SBS. Sandy inundation zone: NYC Open Data; 2015. https://data.cityofnewyork.us/Environment/Sandy-Inundation-Zone/uyj87rv5. Accessed 15 Jan 2020.

Schwartz RM, Patricia Rothenberg BA, Samantha M, Kerath MS, et al. The lasting mental health effects of hurricane Sandy on residents of the rockaways. Journal of Emergency Management. 2016;14:269-79. https://doi.org/10.5055/jem.2016.0292.

Schwartz RM, Rasul R, Kerath SM, et al. Displacement during hurricane Sandy: the impact on mental health. Journal of Emergency Management. 2017;16:17-27.

Schwartz RM, Sison C, Kerath SM, et al. The impact of hurricane Sandy on the mental health of New York area residents. Am J Disaster Med. 2015;10:339-46. https://doi.org/10.5055/ajdm.2015.0216.

Sellers C. Race, ethnicity, and flooding; n.d. https://inequality.studies.stonybrook.edu/wordpress/mapping-sandys-inequalities/ race-ethnicity-and-flooding/. Accessed 26 Apr 2020.

Serre $D$, Heinzlef $C$. Assessing and mapping urban resilience to floods with respect to cascading effects through critical infrastructure networks. International Journal of Disaster Risk Reduction. 2018;30:235-43. https://doi.org/10.1016/j.ijdrr. 2018.02.018

Shively D. Flood risk management in the USA: implications of National Flood Insurance Program changes for social justice. Reg Environ Chang. 2017;17:1663-72. https://doi.org/10.1007/s10113-017-1127-3.

Siders AR. Social justice implications of US managed retreat buyout programs. Clim Chang. 2019;152:239-57. https://doi.org/ 10.1007/s10584-018-2272-5.

Stevens MR, Song Y, Berke PR. New urbanist developments in flood-prone areas: safe development, or safe development paradox? Nat Hazards. 2010;53:605-29. https://doi.org/10.1007/s11069-009-9450-8.

US Census Bureau. When to use 1-year, 3-year, or 5-year estimates: The United States Census Bureau; n.d.-a. https://www. census.gov/programs-surveys/acs/guidance/estimates.html. Accessed 15 Jan 2020a.

US Census Bureau. Instructions for applying statistical testing to the 2013-2017 ACS 5-year data: The United States Census Bureau; n.d.-b. https://www2.census.gov/programs-surveys/acs/tech_docs/statistical_testing/2017StatisticalTesting5year. pdf? Accessed 15 Jan 2020b.

Walker G, Burningham K. Flood risk, vulnerability and environmental justice: evidence and evaluation of inequality in a UK context. Crit Soc Policy. 2011;31:216-40. https://doi.org/10.1177/0261018310396149.

Ward PJ, Moel H, Aerts JCJH. How are flood risk estimates affected by the choice of return-periods? Nat Hazards Earth Syst Sci. 2011;11:3181-95. https://doi.org/10.5194/nhess-11-3181-2011.

Wriggins J. Flood money: the challenge of U.S. flood insurance reform in a warming world. Penn St L rev. 2014;119:361.

Xian S, Lin N, Hatzikyriakou A. Storm surge damage to residential areas: a quantitative analysis for hurricane Sandy in comparison with FEMA flood map. Nat Hazards. 2015;79:1867-88. https://doi.org/10.1007/s11069-015-1937-x.

Zarrilli DA. Appeal of FEMA's preliminary flood insurance rate maps for new York City. New York: Mayor's Office of Recovery and Resilience; 2015.

\section{Publisher's Note}

Springer Nature remains neutral with regard to jurisdictional claims in published maps and institutional affiliations.

Ready to submit your research? Choose BMC and benefit from:
- fast, convenient online submission
- thorough peer review by experienced researchers in your field
- rapid publication on acceptance
- support for research data, including large and complex data types
- gold Open Access which fosters wider collaboration and increased citations
- maximum visibility for your research: over 100M website views per year
At BMC, research is always in progress.
Learn more biomedcentral.com/submissions

